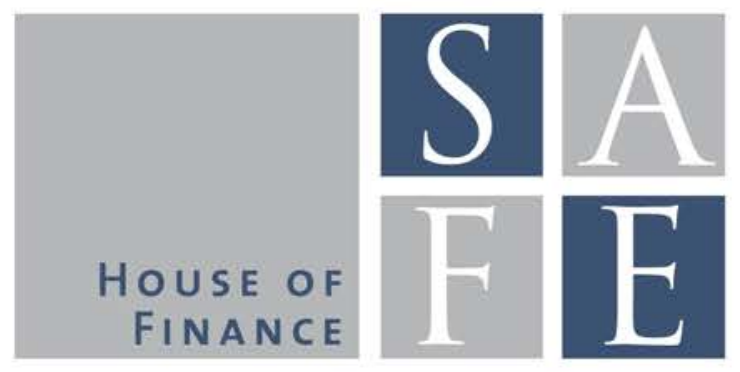

WORKING PAPER SERIES

Marcel Grupp

\title{
Taking the Lead: When Non-Banks Arrange Syndicated Loans
}

SAFE Working Paper No. 100

SAFE I Sustainable Architecture for Finance in Europe

A cooperation of the Center for Financial Studies and Goethe University Frankfurt 


\section{Non-Technical Summary}

Syndicated loans are the most important source of newly originated corporate finance in the U.S. Since the mid-1990s, this market developed significantly in size and relevance attracting more and more non-bank investors. The reasons for them entering this market are mainly the introduction of bank loan ratings by Moody's and S\&P that increase transparency for potential investors and the emergence of specialized loan trading desks within banks enabling investors to trade loan shares among themselves. However, the non-bank investors such as captive finance companies, private equity funds, insurance firms and hedge funds did not only focus on investing in loans but were also competing more often for the lead arranger role. This type of lender is in charge of the borrower screening and monitoring and has been typically awarded to banks in the past.

In this paper, I therefore try to answer the question of why do non-bank lead arrangers exist in this market and what helps them in competing against banks. Additionally, I shed light on how the type of lead arranger influences the composition of a loan syndicate and the loan pricing.

My results indicate that non-banks are able to compete against banks in arranging syndicated loans due to three reasons: First, some of them benefit from looser regulatory requirements enabling them to compete for loans when banks are constraint. Second, non-banks have specialized expertise in industry niches helping them to succeed with their loans. Finally, nonbanks focus on a special group of borrowers that are not asking for cross-selling of other services

which is a crucial aspect in lending by bank lead arrangers. These borrowers tend to be more opaque, less experienced but not more risky than borrowers affiliated to bank lead arrangers. In terms of loan syndicate composition, non-banks syndicate less often than banks. If they syndicate, however, they prefer, to a higher degree than banks, participants that help them to reduce information asymmetries. Finally, non-banks charge 105 basis points more than banks, which is a markup of around $38 \%$ compared to an average bank spread of 274 basis points. This markup is a compensation for serving more opaque borrowers, for higher information asymmetries between lead arranger and participants and it is countercyclical as it decreases if lending competition is lower and vice versa.

My paper helps regulatory authorities to understand the specialization of different types of lead arrangers in the most important market for corporate finance in the U.S. As I can show, non-banks play a crucial role for the financing of opaque, inexperienced lenders which often stick to nonbanks for subsequent loans. My results therefore suggest that regulatory authorities should supervise non-bank institutions active in lending markets with the same scrutiny as compared to banks. 


\title{
Taking the Lead: \\ When Non-Banks Arrange Syndicated Loans
}

\author{
Marcel Grupp ${ }^{1}$
}

This Version: April 2015

\begin{abstract}
In the mid-1990s, institutional investors entered the syndicated loan market and started to serve borrowers as lead arrangers. Why are non-banks able to compete for this role against banks? How do the composition of syndicates and loan pricing differ among lead arrangers? By using a dataset of 12,847 leveraged loans between 1997 and 2012, I aim to answer these questions. Non-banks benefit from looser regulatory requirements, have industry expertise which helps them in the screening and monitoring of borrowers and focus on firms that ask for loans only instead of additional cross-selling of other services. I can show that non-banks specialize on more opaque and less experienced borrowers, are more likely than banks to choose participants that help to reduce potentially higher information asymmetries and earn 105 basis points more than banks.
\end{abstract}

Key Words: Non-bank lead arrangers, syndicated loans, spread premium

JEL Classification: G21, G23, G32

I thank Felix Freudenberg, Andrej Gill, Axel Haus, David Heller, Magdalena Ignatowski, Marie Lalanne, Julian Mattes, Ioannis Spyridopoulos, Sascha Steffen, Uwe Walz, Jochen Werth, Christine Zulehner and participants at the Management and Microeconomics Brown Bag Seminar in Frankfurt, the FIRM Innovation platform in Frankfurt and the Eastern Finance Association Conference in New Orleans for helpful comments.

\footnotetext{
${ }^{1}$ Goethe University Frankfurt, SAFE Center of Excellence. Address: House of Finance, Theodor-W.-Adorno-Platz 3, 60629 Frankfurt, Germany. Email: marcel.grupp@gmail.com. I gratefully acknowledge research support from the Research Center SAFE, funded by the State of Hessen initiative for research LOEWE.
} 


\section{Introduction}

From the mid-1990s onwards, the syndicated loan market developed significantly to the most important source of newly originated corporate finance in the U.S. today (see Sufi (2007)). Main reasons are the introduction of bank loan ratings by Moody's and S\&P which increased transparency for potential investors and the emergence of specialized loan trading desks within banks that enable investors to trade loan shares in a new secondary loan market as described in Lim et al. (2014). With these improvements, a growing number of institutional investors such as captive finance companies, insurance firms, hedge funds, private equity sponsors and CDOs entered this market. Ivashina and Sun (2011) present evidence of this increased importance as "in 2007 , institutional investors funded $62 \%$ of primary leveraged loan issuance, up from $15 \%$ in 2001." However, institutional investors do not focus only on investing in loan syndicates as participants but gain more and more influence on the borrower selection and monitoring process by receiving the lead arranger role, a lender role that has typically been awarded to banks in the past.

From these developments several questions emerge naturally: Why do non-bank lead arrangers exist in the market? What exactly helps them to compete against banks? How does a different type of lead arranger influence the composition of loan syndicates and the loan pricing? These questions are highly interesting for two reasons. First, it helps in understanding a less intuitive choice of the borrowers as it is not clear why they should tap newly emerging, nontraditional lenders instead of traditional bank lenders. Second, it sheds light on how competition in this market works and how different types of financial intermediaries specialize on different types of borrowers. To my knowledge, existing research (e.g., Nandy and Shao (2010), Ivashina and Sun (2011) or Lim et al. (2014)) analyze non-banks without taking into account that there might be different lender roles assumed by non-banks.

I aim to answer these questions by using a dataset of 12,847 syndicated loans to U.S. nonfinancial borrowers from 1997-2012 with available accounting data; the main data sources are Dealscan and Compustat. My results lead to four major conclusions. 
First, non-bank lead arrangers are able to develop and sustain their syndicated loan market share due to looser regulation, industry expertise and focus on a special group of borrowers: Some non-banks benefit from looser regulatory requirements which help them to compete for loans. The mechanism is that banks have to set lending limits which might constraint them to expand their lending business. Furthermore, respecting all regulatory constraints comes at a cost as it might lead to the decision to not serve every borrower that otherwise would have been served. As smaller captive finance players as well as private equity firms and hedge funds are not regulated by national authorities, they have an advantage compared to banks. Additionally, non-banks have specialized expertise in industry niches which help them to be successful in conducting due diligence and monitoring. Finally, as non-banks are constraint in offering crossselling of other services, they focus on borrowers that typically are not asking for cross-selling and rather look for specialized lenders. These borrowers are more opaque, rather inexperienced and have lower leverage ratios. These results are pieces of evidence in contrast to existing research which postulates that non-bank investors should be focusing on risky borrowers. However, as I will detail in the next sections, these authors do not differentiate between non-bank lead arrangers and non-banks investing in bank-arranged loans. As I will show, it is the latter group which concentrates on riskier borrowers.

Second, non-bank lead arrangers syndicate less often than banks and are more likely to keep entire loans on their balance sheets when more information on the borrower is available. If they syndicate, however, they prefer, to a higher degree than banks, participants that help them to reduce information asymmetries.

Third, non-bank lead arrangers charge 105 basis points more than bank lead arrangers while bank-arranged loans with non-bank participants charge only a markup of around 24 basis points. Existing research mixes these two types of non-bank involvements and comes to an average markup of 54 basis points. My results show that this markup is mainly driven by non-banks serving as lead arranger.

Finally, the non-bank lead arranger markup is a compensation for serving more opaque borrowers, for higher information asymmetries between lead arranger and participants and is 
countercyclical as it decreases if lending competition is lower and banks tighten their lending standards.

The paper is organized as follows: Section 2 presents stylized facts about syndicated lending in general. Section 3 develops testable hypotheses. Section 4 explains and summarizes the data set. Section 5 discusses the empirical results. Section 6 concludes.

\section{Overview of Syndicated Lending}

\subsection{Roles of Lenders and the Syndication Process}

In comparison to standard single-lender loans, syndicated loans are structured, arranged and monitored by a financial intermediary called lead arranger which invites other lenders to invest in the loan. This makes clear that the lead arranger possess an extremely important role for the syndicate and its success as it is the lead arranger which facilitates allocating investor money to borrowers with financing needs. Following the explanations in Sufi (2007), the lead arranger is responsible for the relationship to the borrower, the primary information collection, the conduction of the due diligence to assess the borrower's creditworthiness, the organization of the syndication process and the borrower monitoring until loan maturity. Participants, in contrast, typically do not establish a relationship to the borrower but rather invest in the loan to fill up the syndicate and to earn a return.

In order to successfully close a loan, the lead arranger organizes the syndication process which is detailed in several papers, e.g. Sufi (2007), Bharath et al. (2011), Ivashina and Sun (2011), and S\&P (2013). The process starts with the borrower asking a financial institution to become the lead arranger which then conducts the due diligence on the borrower's creditworthiness and negotiates non-price loan characteristics such as amount, maturity, covenants with the borrower. In a next step, the lead arranger assesses informally the interest of potential participants to invest in the loan. Based on this information, the lead arranger sets a first interest rate to start the syndication. This process is similar to a book-building where potential investors are asked how 
much they want to invest at a certain price. The lead arranger therefore receives feedback similar to investor A would like to invest 5mn USD at 200 basis points or $7 \mathrm{mn}$ USD at 250 basis points ${ }^{2}$. Based on this sealed-bid auction a certain price is defined at which the loan amount is financed entirely. If the loan is oversubscribed at the estimated first interest rate, the spread is reduced (which is called flexed down) or increased (flexed up) if the loan is undersubscribed.

\subsection{Information Asymmetry Problems}

A crucial aspect of syndicated lending is the importance of information asymmetry problems. Ivashina (2009) provides a good overview of these information problems in syndicated lending and shows their importance by estimating their size at approximately $4 \%$ of total credit costs. As syndicated loans can be classified as in-between relationship-driven single-lender loans and more transactional public debt, two cases of information asymmetry are relevant for syndicated loans.

First, there is an adverse selection problem as the lead arranger might have incentives to syndicate low quality loans or not screen the borrower diligently. As a result, the lead arranger has to take a larger loan share in order to signal the good credit quality of the borrower as stated by Sufi (2007). Second, there is an additional moral hazard problem as the incentive to engage in costly and unobservable monitoring after the loan agreement is reduced the more of the loan is syndicated to outside investors. As described in Sufi (2007), a solution to this specific information problem is to form smaller syndicates. So, while the first part of the problem is more about information asymmetries towards the borrower, the latter part consist of information asymmetries towards the other participants in the loan syndicate.

\footnotetext{
${ }^{2}$ The interest rate is usually set as a markup to a floating interest rate such as the LIBOR
} 


\subsection{Case Example}

In order to get an idea of how exactly a syndicated loan package is structured, I present a case example in Figure 1. The borrower is Applied Extrusion Technologies which manufactures packaging and labels mainly for food products. I choose a company from this industry classification as it is one of the most important industries for non-bank-arranged lending (rank 8), however, it plays no important role in bank-arranged lending (rank 279) which might be a piece of evidence that non-bank lead arrangers focus on industry niches and have specific monitoring skills in order to succeed in serving these industries (see section 5.1 for a more detailed analysis). At the loan origination, it was a young firm just founded 17 years ago and rather small with around 405mn USD of total assets.

The loan package consists of two loans, one revolving credit facility and an amortizing term loan, which are counted as two separate loans in my dataset. Both loans are arranged by General Electric Capital and are syndicated to Black Diamond Capital, a private equity firm, and Merrill Lynch Capital. Such a small syndicate is quite typical for a non-bank-arranged loan as can be seen in the descriptive statistics section 4.2. Both loans are used for working capital purposes.

\section{Figure 1}

Case Example Non-Bank Syndicated Loan

\section{Company Overview}

Company

Business model

Ranking Industry Among Non-Bank Lead Arrangers

Ranking Industry Among Bank Lead Arranger

Age (in Years)

Total Assets (mn USD)
Applied Extrusion Technologies

"[...] produces oriented polypropylene (OPP) films used to make flexible packaging, as well as labeling for plastic, metal, and glass containers"

(Hoovers)

8

279

17

405 
Loan Package Overview

Loan Type

Maturity

Facility Amount (mn USD)

Spread over LIBOR (bps)

Loan Purpose

Secured

Lender (Roles)
Revolving credit facility Term Loan

03/10/2003 - 06/10/2008 03/10/2003 - 06/10/2008

$50 \quad 50$

275375

Working Capital

Yes

General Electric Capital (Admin Agent)

Black Diamond Capital (Participant)

Merrill Lynch Capital (Participant)

\section{Development of Hypotheses}

At first glance, the existence of non-bank lead arrangers seems to be a puzzle. In a market where information asymmetries are large and crucial (see section 2.2), it seems less intuitive for borrowers to tap non-traditional lenders instead of banks. The reason is that non-banks are quite likely to suffer from higher information asymmetries than banks due to their lower track record in syndicated lending being new entrants to the market. Bharath et al. (2011) show for example that borrowers benefit from relationship lenders through lower spreads which would lead to the conclusion that it should be difficult for new entrants to compete in such a market. The same thinking applies to examining additional banking products such as public securities underwriting. Drucker and Puri (2005) show that firms that receive lending and underwriting services from the same bank typically benefit as there are informational economies of scope once the bank established the relationship. However, even after non-banks entered the syndicated loan market, one could have expected banks to compete them out of the market again. Therefore, when thinking about these aspects, several questions arise naturally: Why do non-bank lead arrangers exist and what enables them to compete in the syndicated loan market? What are the implications

of different types of lead arrangers for the composition of the syndicates? How does loan pricing differ among non-bank- and bank-arranged loans?

In order to answer these questions, I start with developing testable hypotheses in the next sub-sections. 


\subsection{Lead Arranger Selection}

As described in section 2.1, the selection of the lead arranger is the first step before the syndication and pricing process actually starts. Understanding the choice made by borrowers would therefore be an important piece of evidence of why non-bank lead arrangers exist and why they can compete in this market.

A good way to start is the regulatory framework in which lead arrangers operate. Regulatory authorities might concentrate on banks only and not focus on shadow banks like the non-bank institutions in my dataset. This could lead to banks syndicating fewer loans than without regulatory requirements as they might be constraint in terms of overall size of their leveraged lending portfolio or some loans might become non-profitable due to higher costs associated with fulfilling regulatory requirements. This is summarized in my first hypothesis:

Hypothesis $H_{1}$ : Non-bank lead arrangers operate in the syndicated loan market as they might benefit from looser regulatory requirements compared to banks.

A next element in assessing the differences among lead arranger types is the ability of conducting due diligence and loan monitoring. This is particularly important as institutions which would not be able to conduct successfully the due diligence and monitoring of the borrower would be driven out of the market as less and less investors would be willing to participate in these loans. As captive finance companies for example started their lending business often in order to promote sales of their industrial parent companies as described in Carey et al. (1998), it is quite likely that non-banks have superior experience in specific industry niches. Additionally, other non-banks such as private equity firms might also have gained significant expertise in industry niches through their restructuring work in past investments. This leads to the next hypothesis:

Hypothesis $\mathrm{H}_{2}$ : Non-banks have superior expertise in specific industry niches which helps them to operate in the syndicated loan market. 
The final aspect, I want to test in order to assess why non-banks exist, is the cross-selling argument. As the following quote from S\&P (2013) points out, banks are looking for borrowers with large cross-selling opportunities:

"If a bank is going to put a loan on its balance sheet, then it takes a hard look not only at the loan's yield but also at other sources of revenue from the relationship, including noncredit business - like cash management services and pension-fund management - and economics from other capital markets activities, like bonds, equities or M\&A advisory work."

As non-banks do not offer most of the services that are typically subject to cross-selling, it is likely that they focus on borrowers where cross-selling is not very important. Following the theoretical and empirical work of Drucker and Puri (2005), Parthasarathy (2007) and Laux and Walz (2009), especially borrowers with lower levels of leverage and more opaque firms (smaller, unrated and younger companies) are looking for specialized lenders that focus only on lending rather than on lending and additional cross-selling. This leads to the next hypothesis:

Hypothesis $\mathrm{H}_{3}$ : As non-banks do not offer most of the cross-selling services, they should attract borrowers with lower leverage ratios and higher opacity (e.g., younger, smaller and unrated firms).

This would be in contrast to existing research, notably Carey et al. (1998), Denis and Mihov (2003), Nandy and Shao (2010) and Lim et al. (2014) which argue that non-banks should focus on riskier borrowers. However, the papers work either with older datasets (Carey et al. (1998) and Denis and Mihov (2003)) or do not focus on non-banks as lead arrangers (Nandy and Shao (2010) and Lim et al. (2014)). They either do not even classify non-banks but rather follow bank slang in defining institutional tranches (Nandy and Shao $(2010)^{3}$ ) or mix non-banks investing in bankarranged loans and non-bank-arranged loans by defining an institutional loan to have at least one non-bank investor irrespective of its role (Lim et al. (2014)). My argument, however, is that non-

\footnotetext{
${ }^{3}$ In their paper, institutional tranches are just defined as having the name of term loan B, C or higher irrespective of the lenders investing in these loans. It could be the case that a non-bank invests in a revolving credit line but not in a term loan B which would not be captured by their approach.
} 
bank lead arrangers and bank lead arrangers that attract non-bank participants differ enormously as the most crucial role, the lead arranger role, differs among these groups.

\subsection{Syndication and Pricing}

\subsubsection{Choice of Syndication vs. Sole-Lender Loan}

After having developed hypotheses of why non-banks could be selected as lead arrangers, I want to analyze the syndication and pricing process. As a first step, I examine how non-banks compose the syndicates as compared to bank lead arrangers. I separate this question into different aspects: First, why do they syndicate at all? And second, if they syndicate, which participants are chosen and for which reasons?

The first question sheds light on the idea that instead of selling loan shares to outside investors, non-banks could just act as sole-lenders and retain the entire loan on their balance sheets. Theoretical background can be found in the strand of literature that deals with information asymmetries in syndicated loans. The aspects of information asymmetry, towards the borrower and towards the syndicate participants have already been introduced in section 2.2. Following the literature, there are three main motives why financial intermediaries should syndicate a loan. First, following Diamond (1991) borrowers develop from private to public debt as the quality of information about the firm increases over time. As syndicated loans share some features of public debt (e.g., shares of the loan are sold to outside investors), the higher the information quality the less monitoring is required which should increase the probability of syndication. Second, higher agency costs between lead arrangers and participants lead to a lower probability of syndication as postulated by Dennis and Mullineaux (2000). Finally, financial intermediaries might want to syndicate loans just for the purpose of diversification as described in Simons (1993). There are several papers emphasizing the advantages of syndication. Ivashina

and Scharfstein (2010) argue that it helps sharing risks from the originating bank towards the participating investors which is valuable for banks if they have to finance themselves costly in 
imperfect capital markets. Additionally, it expands credit supply as it lowers the threshold for risk in new originations due to the possibility of distributing risks among other investors.

As non-bank lead arrangers should have higher agency costs than bank lead arrangers due to being new entrants to the market and their lower market shares compared to banks, non-banks should decide more often to not syndicate loans. However, there are no reasons to believe that the three drivers are different among types of lead arrangers. This leads to my fourth hypothesis: Hypothesis $\mathrm{H}_{4}$ : Although non-banks should syndicate less often, the main drivers influencing positively the probability of syndicating a loan (more information available, lower agency costs between lead arranger and participants, need for diversification) remain the same across lead arranger types.

\subsubsection{Choice of Participants}

After having decided to syndicate, the lead arranger has to choose the participants to invest in the loan. As shown by Sufi (2007), financial intermediaries tend to choose participants that help them to reduce information asymmetry problems, e.g. participants that are geographically closer to the borrowers or more likely to know the borrower (and the lead arranger) from past debt deals. As non-banks (being new entrants to the market) are likely to have a lower reputation and market share, they should more suffer from higher information asymmetries. Therefore, this should imply that non-banks prefer participants that help solving these information problems as stated by the following hypothesis:

Hypothesis $H_{5}$ : In choosing concrete participants, non-bank lead arrangers rely to a higher extent than banks on specific participants that help to reduce information asymmetries. 


\subsubsection{Loan Pricing}

As a final step, I want to analyze the loan pricing differences between non-bank and bank lead arrangers. The existing evidence on non-bank loan pricing is rather mixed and is not differentiated among types of non-bank lender roles. While Carey et al. (1998), Nandy and Shao (2010) and Lim et al. (2014) show that non-banks might be related to higher loan spreads, Ivashina and Sun (2011) show that institutional loans tend to have lower spreads which are attributed to higher institutional demand pressure. My argument, following the hypotheses discussed above, is more in line with the former group of researchers: I expect non-bank lead arrangers to receive higher spreads. There are four potential reasons that might lead to higher spreads for non-banks compared to bank lead arrangers:

Non-banks should ask for higher spreads as cross-selling opportunities apart from follow-on financings are rather limited as they typically do not offer many other banking services such as public securities underwriting. As non-banks should therefore attract borrowers which are not interested in cross-selling, they might ask for higher spreads in order to break even with the loan on a stand-alone basis. Banks, however, should be able to offer loans at lower spreads in the case of cross-selling of other services due to lower origination costs as a consequence of their informational economies of scope as detailed in Laux and Walz (2009). Second, the assumed higher opacity of non-bank borrowers should lead to higher spreads as it is more costly to screen and monitor them. Third, following the cited papers above, there might be the case that nonbanks focus on risky borrowers and therefore ask for higher prices. Finally, as non-banks are likely to suffer from higher information asymmetries towards potential participants due to less experience and lower market share, the participants might not trust the monitoring effort from non-banks to the same extent they trust bank lead arrangers and could ask for compensation.

Additionally, the loan pricing of non-banks might differ from banks due to the competitive landscape and is based on anecdotal evidence that I was able to collect during a talk with an Executive Vice President of the finance division of one of the companies in my data set that received a loan syndicated by a non-bank: "However, the banks are less reliably supportive and more sensitive to the pendulum swings of the economic herd mentality than some of the more 
non-traditional lenders." 4 This would lead to an influence of competition on the difference in loan pricing between non-bank and bank lead arrangers.

These arguments are summarized in my last two hypotheses:

Hypothesis H6a: Non-bank-arranged loans should have higher spreads than bank-arranged loans.

Hypothesis $H_{6 b}$ : The potential markup might be due to missing cross-selling opportunities, borrowers with expected higher opacity or expected higher risks or higher information asymmetries towards participant investors. Additionally, the difference in pricing should fluctuate with the competitive situation in the lending industry.

\section{$4 \quad$ Data Set and Descriptive Statistics}

\subsection{Data Set}

My data set consists of 12,847 leveraged loans to U.S. non-financial borrowers from Reuters LPC's Dealscan database covering a period from 1997-2012.5 This time period is chosen because institutional loan investments started in the mid-1990s after Moody's \& S\&P introduced ratings for syndicated loans (see Lim et al. (2014)). I focus on leveraged loans as institutional investors mainly invest in these debt contracts. Leveraged loans are identified using the Dealscan market segment classifications "(High) Leveraged" and "LBO". All loan tranches in my dataset can be either classified as revolver or term loans as I delete all non-standard loan types from the analysis following Lim et al. $(2014)^{6}$. Similar to other authors, I delete all non-senior, non-LIBOR loans and loans with missing spread or lender information. Finally, I match accounting data from

\footnotetext{
$45^{\text {th }}$ March 2014

${ }^{5}$ Financial borrowers have been defined as having an SIC code of 6000-6700

${ }^{6}$ This includes bankers acceptance, bridge loans, deferred payment leases, demand loans, bonds, floating rate notes, notes, guarantees, non-committed guidance lines, mortgage facilities, other/undisclosed loans, multi-option facilities, leases and standby/trade letters of credit
} 
Compustat using the file provided by Michael Roberts ${ }^{7}$ and cross-check it by hand-matching company names. All variables used in the analyses are defined in Table 1.

A critical part is the classification of lenders in banks and non-banks. Here, I follow closely the methodology in Lim et al. (2014). I start to identify bank lenders and use the Dealscan industry classifications and SIC codes. All lenders that have the industry types "U.S. Bank", "African Bank", "Asian-Pacific Bank", "Foreign Bank", "Eastern Europe/Russian Bank", "Middle Eastern Bank", "Western European Bank" or "Thrift/S\&L" or have the SIC codes 6011-6082, 6712, 6719 or 6211 are classified as banks. To be more conservative, non-bank lenders with banks as ultimate parents are also classified as banks.

As a next step, I start the classification of non-banks with the identification of insurance companies. Therefore, I use the industry type "Insurance Company" or the SIC codes 6311-6361, 6399 or 6411 . Identifying other types of non-banks is more time-consuming as there are no clear SIC codes which only stand for one of these types. Finance companies are being classified based on the Dealscan industry type "Finance Company" whereas hedge funds, private equity firms, mutual funds or CDOs/CLOs are being classified as investment managers based on their appearance in the Preqin database, their Dealscan industry types ("Mutual funds", "Institutional investor- prime funds", "Institutional investor - Other", "Institutional investor - Hedge fund" or "Vulture fund") and on their description in the Bloomberg BusinessWeek database which provides business model descriptions of most public and private companies. These investment managers are typically active in this special debt market to diversify risk and returns or to offer dedicated credit funds to their investors. Corporates or lenders with the industry type "Other" that cannot be added to the other classifications are defined to form the last group of non-banks. All lenders have been manually cross-checked with the Bloomberg BusinessWeek database.

By classifying the lender roles, I follow the Dealscan terminology and use the same approach as in Ivashina (2009): The administrative agent is defined to be the lead arranger as it is "the bank that conducts due diligence, handles all the payments, and monitors the loan." (Ivashina (2009)).

\footnotetext{
${ }^{7}$ Can be accessed via http://finance.wharton.upenn.edu/ mrrobert/styled-9/styled-12/index.html
} 
If there is no administrative agent, I follow Ivashina (2009) and define lenders with the roles of agent, arranger, book runner, lead arranger, lead manager or lead bank to be the lead arrangers. For a minority of tranches, I am still not successful in identifying the lead arranger and therefore define the lender roles of co-agent, co-manager, co-arranger, mandated arranger or mandated lead arranger to be the lead bank. All other lenders are then classified as participants. To be more conservative I delete all loan packages where there are contradicting types of lead arrangers across facilities as this might be a sign of mistakes in assigning lender roles to the investors.

My final sample consist of 12,847 loan tranches from 8,193 loan packages (made out to 3,591 firms) out of which 746 loan tranches are non-bank-arranged (5.8\%) and further 3,075 loan tranches are bank-arranged with at least one non-bank participant (23.9\%).

\subsection{Descriptive Statistics}

Panel A of Table 2 presents the descriptive statistics for non-bank and bank lead arrangers together with the Student's t-test of their differences.

Comparing the two groups, non-bank lead arrangers focus on less risky borrowers with lower leverage ratios and on more opaque borrowers. The opaque borrowers are more likely to be unrated, smaller and younger firms with lower public debt or syndicated loan experience. This provides a first confirmation of my hypothesis $\mathrm{H}_{3}$. Table 2 also shows that the more opaque nonbank borrowers are not necessarily financially constraint as the $\mathrm{KZ}$ index developed by Kaplan \& Zingales (1997) and Lamont et al. (2001) is no significantly different among borrowers from the different lead arranger types. Additionally, I test a cross-selling opportunity dummy which equals 1 if the borrower will issue public debt or equity, will become active in an M\&A event or will receive financing through a syndicated loan in the next 12 months (and 0 otherwise). The idea behind this variable is that lead arrangers who built up a relationship to the borrower should be able to forecast these short-term cross-selling opportunities. The results show that non-banks do indeed focus on borrowers that are significantly less likely to have cross-selling opportunities in the future and therefore are players specialized on a specific part of the syndicated loan market 
confirming the idea behind hypothesis $\mathrm{H}_{3}$ that non-banks specialize on borrowers that match their abilities. Borrowers with upcoming cross-selling opportunities therefore seem to choose banks rather than non-banks as lead arrangers. When it turns to loan purposes, there are no differences for the major loan purposes between non-bank and bank lead arrangers.

One of the most striking differences between these two groups is the difference in the spread. Non-bank-arranged loans cost 102 basis points more than bank-arranged loans. This is an economically significant difference and very interesting given that the non-bank loans are even less risky than the comparison group. Furthermore, the loans are syndicated to fewer investors and the lead arrangers are geographically closer to the borrower which is evidence that non-bank lead arrangers are taking steps against the higher information asymmetry compared to banks. Finally, the data shows that non-bank lead arrangers have less lending experience as they are less likely to be known from past lead arranger appointments and have less relationships to the participants.

Additionally, I want to shed light on the different funding sources for the different lead arranger types. Panel B of Table 2 shows some descriptive statistics from my data set for lead arrangers where I could find publicly available data (banks and finance companies) and from related papers (Ang et al. (2011) who analyze leverage in hedge funds and Axelson et al. (2013) who do similar work for private equity). While the equity and leverage ratios are calculated based on total assets, the long-term debt ratio shows the relation to total debt. Unfortunately, I was not able to get comparable long-term debt ratios for hedge funds and private equity as the authors only described it qualitatively. The funding structure of banks is quite remarkably as they have the lowest equity ratio values across the four types of lead arrangers with on average $9 \%$. The non-bank lead arrangers have all significantly higher values of equity (and therefore lower leverage ratios) with hedge funds being an outlier compared to the other types. When examining the debt structure, one can see that finance companies and private equity funds have higher amounts of long-term debt while hedge funds have rather low levels of long-term debt "as there are very few hedge funds able to directly issue long-term debt or secure long-term borrowing" 
(Ang et al. (2011)). Banks have also very low levels of long-term debt compared to their entire debt.

\section{Empirical Results}

\subsection{Lead Arranger Selection}

One aspect of why non-banks might be able to compete against banks could be that they benefit from looser regulatory requirements as stated in hypothesis $\mathrm{H}_{1}$. This could lead to non-banks being able to serve customers while banks might be restricted to provide new loans.

(Leveraged) lending in the U.S. is supervised by the Federal Reserve or the Office of the Comptroller of the Currency (OCC) which are very close to each other in their approach. In their publication Interagency Guidance on Leveraged Lending (2001) both authorities present their regulatory standards. They force all supervised institutions to set lending limits on leveraged loans "consistent with their risk appetite and financial capacity". Additionally, sub-limits e.g. by collateral type, loan purpose, industry have to be set. After each of the yearly loan portfolio reviews, the regulators can adjust underwriting guidelines and even force lenders to write off some loans. Although large finance companies are regulated by one of the two authorities, which means that they have no regulatory advantage compared to banks, there are non-bank lenders such as smaller finance companies, hedge funds, private equity funds that are not regulated and therefore have an advantage compared to the supervised entities. ${ }^{8}$ A recent example provided by Reuters shows that this regulatory advantage might help to win new loan syndication mandates as banks are restricted by regulatory authorities: "U.S. regulators are keeping closer tabs on how banks are managing the high-risk lending that triggered the financial crisis, including leveraged loans financing acquisitions and dividend payments. [...] The result is that they (banks) are going to be able to lend less money," said Brett Barragate, co-head of the banking and finance practice

\footnotetext{
8 Whether or not a financial institution is regulated and by whom can be checked on the website of the Federal Financial Institutions Examination Council (www.ffiec.gov/consumercenter/default.aspx)
} 
at Jones Day."9 Therefore, hypothesis $\mathrm{H}_{1}$ can be confirmed as some non-banks could be in the market as other regulated entities might not be able to expand their lending business due to regulatory hurdles.

Additionally, non-banks might be able to develop or maintain their lending market share due to their ability in due diligence and monitoring. The idea is that if non-banks would not have special skills compared to banks, borrowers would rather ask banks to arrange their loans and/or banks would compete for the non-bank lead arranger role. Following my hypothesis $\mathrm{H}_{2}$, I will check whether non-banks have superior industry expertise which would enable them to conduct due diligence and monitoring successfully.

To get an idea about the industry distribution, I present a ranking of the top 20 4-digit SIC codes where non-banks have syndicated loans in Table 3. The span of industries is quite diverse and is a first piece of evidence in favor of hypothesis $\mathrm{H}_{2}$. The reason is that there are industries where e.g. finance companies might have specific industry knowledge and could therefore be better in the due diligence and monitoring of borrowers than banks. Examples are GE Capital with General Electric as parent company which might have significant expertise in industries like "in vitro and in vivo diagnostic substances" (rank 3) or "fabricated rubber products" (rank 18) as General Electric is exactly operating in these industries (healthcare and advanced materials) and GMAC Commercial Finance with General Motors as parent company which could explain industry appearances in the ranking such as "motor vehicle parts and accessories" (rank 7)). Additionally, private equity firms which also serve occasionally as lead arrangers could also be able to have gained significant experience in industry niches through their equity investments. Strikingly, most of the industries that are relevant for non-bank lead arrangers are less relevant or not relevant at all for bank lead arrangers as can be seen at the positions in their ranking (the average rank of the non-bank top 20 industries is 83 for bank lead arrangers). This is evidence that non-banks are likely to have specific monitoring skills for borrowers from these industry

${ }^{9}$ http://www.reuters.com/article/2013/11/22/idUSL5N0J726W20131122, accessed 03/09/2014 
niches as otherwise banks would compete and succeed in these industries. Therefore, this would a piece of evidence in favor of my hypothesis $\mathrm{H}_{2}$.

The final aspect, I want to analyze, is why non-bank lead arrangers are actually chosen by borrowers and whether borrowers select their arrangers consistent with their need of crossselling of other services. In section 3.1, I derive from standard literature that more opaque borrowers with lower leverage ratios are more likely to hire lenders that are not offering crossselling of other services. These descriptions match quite well my descriptive statistics of borrowers mandating non-banks with the syndication of their loans as shown in Table 2 and the value of the cross-selling opportunity variable as already described in section 4.2. Now, I test the same idea in a multivariate framework by estimating a probit regression with a dependent variable that is 1 for loans with non-bank lead arrangers and 0 for loans syndicated by banks. Independent variables are my standard control variables used in all models covering borrower, loan and competition/macroeconomic characteristics as well as time, industry, loan purpose and loan type fixed effects. Following the hypothesis $\mathrm{H}_{3}$, I would expect that variables measuring opacity such as (smaller) size, being unrated or having no (public) debt experience and lower leverage ratios to be significant in explaining the choice of non-bank. The results in Table 4 confirm this view as smaller companies, which are inexperienced in terms of past public debt and syndicated loan issuances and firms with higher required monitoring levels (secured or new loans) receive loans from non-banks. The leverage ratio and other risk variables are not significant indicating that non-banks do not specialize on serving risky borrowers. Furthermore, my univariate cross-selling results are confirmed as borrowers with short-term cross-selling needs are more likely to ask banks instead of non-banks to syndicate their loans. Finally, borrowers do not switch from non-banks to banks as having been financed by a non-bank arranged syndicate increases the likelihood of having a non-bank lead arranger again.

To summarize, non-banks seem to have graduated from a focus on risky borrowers as described by Carey et al. (1998) towards lenders with special monitoring skills and a focus on opaque borrowers that do not require cross-selling of other services. This is an important factor in explaining why non-banks exist in the lending market as they would probably disappear if all 
borrowers would only want to get loans from entities that are also able to sell them additional services such as e.g. M\&A advisory. As a conclusion, I clearly confirm my hypothesis $\mathrm{H}_{3}$.

\subsection{Syndication and Pricing}

\subsubsection{Choice of Syndication vs Sole-Lender Loan}

After having examined why non-banks are selected as lead arrangers and which factors help them to compete against banks, I want to investigate the differences in the syndication and pricing processes. As a first step, I analyze the decision that each lead arranger has to take: Do I want to finance the entire loan or do I want other lenders to invest in my loan? The first part of my hypothesis $\mathrm{H}_{4}$ is confirmed by the descriptive statistics in Table 2. Non-bank lead arrangers do indeed syndicate significantly less loans compared to banks which is in line with the idea that non-banks suffer from higher information asymmetries. The second part of hypothesis $\mathrm{H}_{4}$ is tested in Table 5. The probit model has a dependent variable which is 1 if the loan is syndicated and 0 otherwise. In order to compare bank with non-bank lead arrangers as stated by the second part of hypothesis $\mathrm{H}_{4}$, all variables are additionally added as interactions with the non-bank-led dummy. As can be seen in the upper part of Table 5, banks are more likely to syndicate loans if more information is available/less monitoring required (larger firms, companies with public debt or higher syndicated loan experience, loans that are being refinanced), lower agency costs (longer maturity, lead arranger was lead arranger for borrower in the past, lead arranger has a higher reputation as measured by the market share) or need for diversification (sponsored loans). Interestingly, loans to borrowers with short-term cross-selling opportunities are more likely to be syndicated maybe as an appetizer for future investment opportunities for potential investors. These firms might then be more likely to invest again in a public debt or equity issuance or in a syndicated loan (e.g., to finance an M\&A event).

Examining the lower part of Table 5, one can see that most interaction variables are insignificant indicating no structural difference among non-bank and bank lead arrangers. 
However, of the four significant differences, size, public debt issuance, refinancing and profitability, the first three can be attributed to the idea of more syndication if more information is available or less monitoring is necessary. The interpretation of these negative coefficients could be that syndicating loans from borrowers with more available information is less important for non-banks as they might want to retain the full exposure if the information quality is good and might not want to invite other participants. This would be in contrast to the business strategy of banks which resembles an originate-to-distribute model. Same applies to profitability as loans from borrowers with higher profitability are less likely to be syndicated.

The results examined in this sub-section partially confirm my hypothesis $\mathrm{H}_{4}$. Non-banks do indeed syndicate less often and respond to similar motives as banks (lower agency costs and need for diversification as drivers of syndication) except for the idea of available information. Nonbanks seem to be willing to retain the loans on their balance sheets if more information is available.

\subsubsection{Choice of Participants}

After having analyzed the decision to syndicate or not, I continue with modeling the choice of participants. To test hypothesis $\mathrm{H}_{5}$ I follow a methodology proposed by Sufi (2007) to estimate the drivers of concrete participant choices in syndicated loans. The question analyzed in Table 6 is what exactly drives the lead arranger's choice of participant A compared to participant B or C. I estimate this with a probit model with a dependent variable that is 1 for all participants in a loan and 0 for all potential participants. The latter group is measured similarly to Sufi (2007) as all participants that have been active in the current year and represent more than $0.5 \%$ of all participants. Beside of the variables I used in the last probit models, I follow Sufi (2007) and add several potential participant variables measuring the relationships among potential participants, lead arrangers and borrowers as well as characteristics of the potential participants: potential participant was former lead arranger for the borrower, potential participant was former participant for the borrower, potential participant was a participant of a former deal of the lead 
arranger, distance between lead arranger and potential participant and between potential participant and borrower and whether the potential participant is a non-bank.

As non-banks suffer more from information asymmetries than banks, I postulate in hypothesis $\mathrm{H}_{5}$ that non-bank lead arrangers rely to a higher extent than banks on specific participants that help to reduce these information asymmetries. The results in Table 6 show that, additionally to the bank lead arrangers effect, non-bank lead arrangers are even more likely to choose participants they know from past deals, participants that are even closer to the borrower and which are non-banks. This shows that non-banks try to minimize the information asymmetries between them and the participants as well as between the syndicate and the borrower. Choosing participants that are closer to the borrowers is therefore a natural strategy when serving more opaque borrowers as discussed in Sufi (2007). Furthermore, non-banks are more likely to attract participants of the same type as they might be better connected among these investors. These results clearly confirm my hypothesis $\mathrm{H}_{5}$.

\subsubsection{Loan Pricing}

After having shown how the syndication and participants decisions differ among the syndication types, I extend the analysis to the loan pricing. As already described, there is some research on differences in loan pricing between banks and non-banks in general without differentiating between lead arranger and participant roles. The results from Nandy and Shao (2010) and Lim et al. (2014) show that non-banks receive around 54 basis points higher spreads.

In order to test whether there are differences among bank and non-bank lead arrangers, I estimate an OLS regression with the all-in drawn spread as dependent variable. This spread includes the annual facility fee and is widely used among researchers. In addition to the standard variables from the probit models such as the cross-selling opportunity which could have an influence on the loan pricing and further loan variables that are fixed after the loan origination such as the final facility amount etc., I add a dummy variable for non-bank-arranged loans. Bankarranged loans therefore serve as base case in this model. The results can be found in Table 7. 
Non-banks receive a markup of 105 basis points compared to bank lead arrangers which is enormous given that bank-led loans charge on average 274 basis points. I therefore can confirm my hypothesis $\mathrm{H}_{6 a}$ that non-banks do indeed charge higher spreads than bank lead arrangers.

The interesting question is now to analyze the drivers of this markup. Based on hypothesis $\mathrm{H}_{6 \mathrm{~b}}$, I test five potential drivers by using interactions of the non-bank lead arranger dummy and variables that proxy for these drivers:

First, the non-bank markup might be a compensation for missing cross-selling opportunities which I test by using my cross-selling opportunities dummy. Second, the markup might be a compensation for serving more opaque borrowers and should therefore increase in variables measuring this opacity, e.g. lower total assets (as used in Bharath et al. (2011)), being unrated (Sufi (2007)) or higher growth opportunities measured as higher market-to-book ratios (Altunbaş et al. (2009)). Third, following Carey et al. (1998), the markup might increase in risk as they promote the idea of non-banks specializing on risky borrowers. Although, I could not find such a specialization in my dataset yet, it might still be the case that non-banks price risk differently compared to banks. I therefore analyze whether the non-bank markup increases with the probability of default (z-score) or leverage of the borrower. Fourth, following the idea of nonbank lead arrangers facing higher information asymmetries, participants could ask for compensation before investing in the syndicate due to the uncertainty between non-bank lead arrangers and the participants. The markup should therefore vary with variables measuring information asymmetries (loans where there has been past deals between lead arrangers and participants or where the lead arranger has a higher reputation as measured by the market share should have a lower markup) or factors influencing the necessary monitoring effort (loans with performance pricing should have lower markups). Finally, the last potential explanation for differences in loan pricing is related to the competitive landscape and is based on the anecdotal evidence mentioned earlier. ${ }^{10}$ This leads to the idea that non-bank markups should fluctuate less

\footnotetext{
10 „However, the banks are less reliably supportive and more sensitive to the pendulum swings of the economic herd mentality than some of the more non-traditional lenders." (Executive Vice President Finance, company of my data set, $5^{\text {th }}$ March 2014)
} 
with variables measuring competition and economic situation (Total HHI and Tightening Standards in my dataset).

The results are presented in Table 8 . The results are in line with the explanations of compensation for opaque borrowers (higher markup if unrated and higher growth opportunities) and higher information asymmetries (higher markup if less lending relationships, lower overall lending market share or no performance pricing). Countercyclical behavior as proposed by the fifth driver does also play a role (markup is lower if competition is low and if banks tighten their lending standards). However, non-banks do not price risks differently than bank lead arrangers. Additionally, missing cross-selling opportunities are no reason to ask for higher prices as nonbanks earn already via the opacity/ information asymmetry markups and therefore might not want to ask for a specific missing-cross-selling-markup especially as they do not offer crossselling services. Therefore, I can partially confirm my hypothesis $\mathrm{H}_{6 \mathrm{~b}}$, as there are elements that do play a role for the pricing gap between non-banks and banks (opacity, information asymmetries, competition) while two other elements (cross-selling and riskiness) are not relevant.

\subsection{Robustness Tests}

In order to test the robustness of my lead arranger choice and syndication results, I run several tests. As a first step, I re-estimate Table 4 adding the $\mathrm{KZ}$ index as measure for financial constraints. The results in Table 9 shows that non-bank lead arrangers are not chosen by financially constraint borrowers as indicated by the descriptive results in Table 2 .

As a next step, I re-estimate Tables 4-6 which are the key models of the syndication process (choice of lead arranger, choice of syndication vs sole-lender loans and choice of participants) by estimating a system of equations. Using the methodology of seemingly unrelated regressions (used e.g., in Gropp et al. (2014)), I am able to estimate the three models in a system while allowing for correlations of the errors across the equations which might be the case if the decisions would be taken simultaneously for example. The results are shown in Table 10. Although the standard errors do change, the results are too small to have an impact on the second decimal. This can be 
explained by the correlations calculated between the equations (and shown at the bottom of Table 10) which are all insignificant. Therefore, this leads to the conclusion that estimating the models separately in the Tables 4-6 is a valid approach as the errors do not correlate.

After having analyzed the syndication process in the last section, it is still open to discuss whether non-banks structure the syndication process with the same quality compared to banks. The question is therefore whether non-banks are as good in syndicating the loans to investors as banks given that non-banks have (see my descriptive statistics in section 4.2) fewer relationships to participants and lower market shares which could impact the quality of the syndication. Therefore, I test two aspects of the syndication quality: First, the ability of the lead arrangers for correctly estimating the loan demand of investors and, second, the actual time that non-banks need to organize the syndication.

As described in section 2.1, the lead arranger sets a starting interest rate for the loan after having talked informally to potential investors. However, it might be the case that the loan is not fully subscribed or even oversubscribed at the pre-defined interest rate due to an incorrect price set by the lead arranger or due to a change in market conditions. These events would then trigger an upward adjustment of the loan pricing (which is called flexed up) in the case of an undersubscription or a downward adjustment (flexed down) in the oversubscription case. An adjustment of the interest rate, however, would signal that the lead arranger was not able to estimate the market demand correctly which sheds light on the syndication abilities. To get an idea of how many loans are actually re-priced, I check manually all commentary fields in Dealscan to detect those loans where the pricing had to be adjusted to clear the market. As can be seen in Panel A of Table 11 non-banks are less likely to adjust loan pricing due to more or less market demand than expected which is evidence that they are better in estimating the marketdemand for their loans compared to bank lead arrangers.

Another factor measuring the efficiency of the syndication process is the time-on-the-market of the loan. This variable has been introduced by Ivashina and Sun (2011) and measures the duration of the syndication process in days. The shorter the duration, the better connected the lead arranger and the higher the efficiency of the syndication process. I calculate the time-on-the- 
market for all loans where the launch date (the start of the syndication process) is available. The results are shown in Panel B of Table 11 and show no significant difference between banks and non-banks.

Summarizing the results in this sub-section, non-banks do not seem to have a clear comparative disadvantage in the syndication process as they are even more likely to estimate the correct market price of their loans.

In a recent paper by Nini (2013), the author shows that non-bank lending might be a substitute for issuing public debt. However, the author only focuses on loans that are called institutional tranche (term loans B, C or higher) but does not make the distinction based on the type of lenders actually invested in each loan. I therefore estimate a small probit model without getting into the same level of details as Nini (2013). My dependent variable is a dummy being 1 if there will be a public debt issuance in the next 3 years and 0 otherwise, the results are reported in Table 12. I find evidence that non-bank-arranged loans are seen as substitute and not loans where non-banks invest as participants but have been syndicated the traditional way (by banks). This might therefore be an additional reason why borrowers are still approaching non-banks compared to banks: They might be too opaque for tapping public debt markets and receive financing from specialized lenders (the non-banks).

Another robustness test reconciles my work with the research in Nandy and Shao (2010) and Lim et al. (2014). These authors show that non-banks focus on riskier borrowers and earn a markup of on average 54 basis points compared to bank-only loans. However, they do not differentiate between non-bank lead arrangers and non-bank participants in bank-arranged loans. Therefore, I want to show that there is a huge difference between non-bank lead arrangers and non-bank participants. While the former group serves opaque and inexperienced borrowers, the latter group is supposed to invest in riskier loans where banks are not able to fill the syndicates with other banks as stated by the other researchers. As a first step, I confirm the idea that nonbank participants are indeed used to fill up riskier syndicates. In a next step, I will show how the loan pricing differ among non-bank participants in bank-arranged loans and non-bank lead arrangers. 
First, I estimate a probit model which is conditional on choosing a bank lead arranger with a dependent variable that is 1 if there is at least one non-bank participant and 0 for bank-only loans. The results are shown in Table 13. As expected, non-banks invest in loans with higher risks (higher leverage, lower profitability, sponsored loans) and higher information asymmetry measured by the distance between lead arranger and borrower. However, they also prefer to invest in loans where they might be able to find external or additional information on the borrowers as having a rating, issued public debt in the past or having higher syndicated loan experience increase the likelihood of attracting non-bank investors.

As a second step, I re-estimate Table 7 by introducing another specific intercept for bankarranged loans with non-bank participants. As can be seen in Table 14, bank-arranged loans with non-bank participants earn a markup of 24 basis points while non-bank lead arrangers earn a markup of 110 basis points both compared to the base case of a bank-only syndicate. The markup of 54 basis points found by Nandy and Shao (2010) and Lim et al. (2014) seems therefore to be a combination of a high markup for loans with non-bank lead arrangers and a smaller markup for bank-arranged loans with non-bank participants.

In order to further test my loan pricing results, I run several additional robustness tests. In Table 15, I re-estimate the model in Table 7 by excluding the largest non-bank General Electric Capital Corp (columns (2) and (3)), adding lead arranger credit rating fixed effects to account for possible difference in refinancing terms (columns (4) and (5)) and lead arranger fixed effects (columns (6) and (7)). In all specifications, the non-bank pricing markup remains significant and varies from 96 to 115 basis points.

I also re-estimate Table 8 by using the modifications described in the paragraph above. The results can be found in Table 16 and confirm the signs and most of the significance levels of the base model in Table 8. My results therefore do also hold when modifying the original model.

As a next step, I rely on the very interesting work by Berg et al. (2014) and Berg et al. (2015) which show that the standard approach in the literature to focus on the all-in drawn spread might not capture the entire loan costs to the borrowers. As they argue in their papers, a syndicated loan 
does not only cost a spread per annum but also an upfront fee for the syndication of the loan, a facility fee (which is included in the all-in drawn spread), a commitment fee which is paid on the unused loan amount in a revolver line, an utilization fee which is paid on the used loan amount and a cancellation fee which has to be paid if the loans is cancelled prior maturity. Following the authors, I estimate the total cost of borrowing which accounts for all these fees by using their formula:

Total Cost of Borrowing $=\frac{\text { Upfront Fee }}{\text { Loan Maturity in Years }}+$ Facility Fee $+(1-$ Prob.Drawn Down $) \times$ Commitment Fee $+P D D \times$ Spread $+P D D \times$ Prob(Utilization $>$ UtilizationThreshold $\mid$ Usage $>0) \times$ Utilization Fee + Prob (Cancellation $) \times$ Cancellation Fee

Using the calibration of the probabilities taken from their paper and following the methodology from Berg et al. (2014), I predict the upfront fee for revolver loans and for term loan separately if it is not available from Dealscan by using all variables from the past models. Table 17 shows the results of the re-estimation of Table 7 and Table 8 by using the total cost of borrowing as dependent variable. The results are very similar to the original results, the loan markup reduces to 95 basis points but is still significantly higher than the bank-arranged loan pricing.

As a final pricing robustness test, I conduct a propensity score matching using Table 4 as a model to estimate the predicted probability of being a served by a non-bank lead arranger. This procedure in my case helps to confirm the results from the loan pricing analysis as it makes the groups to be compared more homogenous. In order to match non-bank-arranged loans to bankarranged loans, I follow Bharath et al. (2011) by using the nearest neighbor estimator with $\mathrm{n}=10$ and $n=50$, the Gaussian and the Epanechnikov estimators. The last two algorithms give more weight to bank-arranged loans that are closer to the non-bank-arranged loan propensity scores. The difference is that the Epanechnikov estimator is calculated with a propensity score bandwidth of $h=0.01$ and therefore limits the sample of bank-arranged loans used for comparison while all observations are used in the Gaussian case. The results are shown in Table 18. Panel A presents the differences in the all-in drawn spread. Although the difference becomes smaller 
compared to the unmatched difference from Table 2, it is still higher than 90 basis points and very significant. In Panel B and C, I re-estimate Tables 7 and 8 by using only the matched bankarranged loans from the nearest neighbor estimators. The results are very similar to Tables 7 and 8 providing evidence that it is the type of lead arranger that matters.

The final question I want to answer is how the higher non-bank loan pricing affects the borrowers after loan origination. One could argue that by using these loans the borrower's financial situation might deteriorate given the high markup. Therefore, I test whether the operating performance of the borrower after loan origination is worse than for the bank-arranged loan borrowers by comparing the development of the probability of default in the years after loan origination (z-score) and the actual default rates during and after loan maturity in Panels A and B of Table 19. The results show that the probability of default is not different among non-bank and bank borrowers for all years expect for the second year which show a significant negative coefficient for non-bank borrowers. The actual rate of default, however, is not different among non-bank and bank borrowers during the loan but significantly lower for non-bank borrowers after loan maturity. To conclude, these results do not show signs of a significant deterioration of the borrower's financial situation once they hire a non-bank as lead arranger.

\section{Conclusion}

In this paper, I try to shed light on the question of why non-bank investors are taking over the traditional bank role of the lead arranger of a lending syndicate. Being the first one, to my knowledge, focusing explicitly on the distinctions among different lender roles and types, I contribute to the existing research in two ways.

On the one hand, I help developing a better picture of the competitive landscape in the syndicated lending market. Non-banks are able to compete in this market as they possess specialized industrial knowledge which helps them winning mandates and successfully arranging loan syndicates. Additionally, they focus on borrowers that are shown to be more likely to ask for specialized lending services rather than packages of lending and cross-selling of other 
services. These borrowers are more opaque, inexperienced and have slightly lower leverage ratios. Finally, some of the non-banks benefit from looser regulatory requirements which help them to compete without having to respect pre-set lending limits. It will be interesting to see how this market evolves given the more recent increase in regulatory attention.

Additionally, I analyze the differences in the composition of the syndicate and loan pricing among non-bank lead arrangers and bank-arranged loans. My main results are that non-bank lead arrangers syndicate less due to higher information asymmetries which they also try to reduce by choosing better informed participants. Additionally, I can show that they charge borrowers 105 basis points more than bank-arranged loans and that this markup is driven by the opacity of the borrower, the information asymmetry within the syndicate and the lending competition and business cycle. 


\section{References}

Altunbaş, Yener, Alper Kara, and David Marques-Ibanez 2009. Large debt financing: syndicated loans versus corporate bonds. The European Journal of Finance, 16, 437-458.

Ang, Andrew, Sergiy Gorovyy, and Gregory B. van Inwegen 2011. Hedge fund leverage. Journal of Financial Economics, 102, 102-126.

Axelson, Ulf, Tim Jenkinson, Per Strömberg, and Michael S. Weisbach 2013. Borrow Cheap, Buy High? The Determinants of Leverage and Pricing in Buyouts. The Journal of Finance, 68, 2223-2267.

Berg, Tobias, Anthony Saunders, Sascha Steffen, and Daniel Streitz 2014. Mind the Gap... The Syndicated Loan Pricing Puzzle Revisited. Working Paper.

Berg, Tobias, Anthony Saunders, and Sascha Steffen 2015. The Total Costs of Corporate Borrowing in the Loan Market: Don't Ignore the Fees. Journal of Finance, (forthcoming).

Bharath, Sreedhar T., Sandeep Dahiya, Anthony Saunders, and Anand Srinivasan 2011. Lending Relationships and Loan Contract Terms. Review of Financial Studies, 24, 1141-1203.

Bradley, Michael, and Michael R. Roberts 2004. The Structure and Pricing of Debt Covenants. Working Paper.

Carey, Mark, Mitch Post, and Steven A. Sharpe 1998. Does Corporate Lending by Banks and Finance Companies Differ? Evidence on Specialization in Private Debt Contracting. The Journal of Finance, 53, 845-878.

Dass, Nishant, and Massimo Massa 2011. The Impact of a Strong Bank-Firm Relationship on the Borrowing Firm. Review of Financial Studies, 24, 1204-1260.

Denis, David J., and Vassil T. Mihov 2003. The choice among bank debt, non-bank private debt, and public debt: evidence from new corporate borrowings. Journal of Financial Economics, 70, 3-28.

Dennis, Steven A., and Donald J. Mullineaux 2000. Syndicated Loans. Journal of Financial Intermediation, 9, 404-426.

Diamond, Douglas W. 1991. Monitoring and Reputation: The Choice between Bank Loans and Directly Placed Debt. Journal of Political Economy, 99, 689-721.

Drucker, Steven, and Manju Puri 2005. On the Benefits of Concurrent Lending and Underwriting. The Journal of Finance, 60, 2763-2799.

Gropp, Reint, Christian Gruendl, and Andre Guettler 2014. The Impact of Public Guarantees on Bank Risk-Taking: Evidence from a Natural Experiment. Review of Finance, 18, 457-488.

Ivashina, Victoria 2009. Asymmetric information effects on loan spreads. Journal of Financial Economics, 92, 300-319.

Ivashina, Victoria, and David Scharfstein 2010. Loan Syndication and Credit Cycles. American Economic Review, 100, 57-61. 
Ivashina, Victoria, and Zheng Sun 2011. Institutional demand pressure and the cost of corporate loans. Journal of Financial Economics, 99, 500-522.

Kaplan, Steven N., and Luigi Zingales 1997. Do Investment-Cash Flow Sensitivities Provide Useful Measures of Financing Constraints?. The Quarterly Journal of Economics, 112 (1), 169215.

Lamont, Owen, Christopher Polk, and Jesús Saá-Requejo 2001. Financial Constraints and Stock Returns. Review of Financial Studies, 14 (2), 529-554.

Laux, Christian, and Uwe Walz 2009. Cross-Selling Lending and Underwriting: Scope Economies and Incentives. Review of Finance, 13, 341-367.

Lim, Jongha, Bernadette A. Minton, and Michael S. Weisbach 2014. Syndicated loan spreads and the composition of the syndicate. Journal of Financial Economics, 111, 45-69.

Nandy, Debarshi, and Pei Shao 2010. Institutional Investment in Syndicated Loans. Working Paper.

Nini, Greg 2013. Institutional Investors in Corporate Loans. Working Paper.

Parthasarathy, Harini 2007. Universal banking deregulation and firms' choices of lender and equity underwriter. Working Paper.

Reserve, Federal, and Office of the Comptroller of the Currency 2001. Interagency Guidance on Leveraged Lending, Washington.

S\&P 2013. A Guide to the U.S. Loan Market, New York, Standard E Poor's.

Simons, Katerina 1993. Why Do Banks Syndicate Loans? New England Economic Review, 45-52.

Sufi, Amir 2007. Information Asymmetry and Financing Arrangements: Evidence from Syndicated Loans. The Journal of Finance, 62, 629-668.

Tykvová, Tereza, and Mariela Borell 2012. Do private equity owners increase risk of financial distress and bankruptcy? Journal of Corporate Finance, 18, 138-150. 


\section{Table 1}

Variable Definitions

\begin{tabular}{|c|c|c|}
\hline Variables & Description & Data Source \\
\hline \multicolumn{3}{|l|}{ Borrower Variables } \\
\hline Z-Score & $\begin{array}{l}\text { Calculated following Tykvová and Borell }(2012) \text { as } \\
0.717^{*} \text { working capital/total assets }+0.847^{*} \text { retained } \\
\text { earnings/total assets }+3.107^{*} \text { EBIT/total assets }+0.420^{*} \text { market } \\
\text { value of equity/total liabilities }+0.998^{*} \text { sales/total assets, where } \\
\text { market value of equity is replaced by book value of equity if } \\
\text { market value is not available; measured one quarter prior } \\
\text { loan agreement }\end{array}$ & $\begin{array}{l}\text { Standard \& Poor's } \\
\text { Compustat }\end{array}$ \\
\hline Leverage & $\begin{array}{l}\text { Long-term debt over total assets; measured one quarter prior } \\
\text { loan agreement }\end{array}$ & $\begin{array}{l}\text { Standard \& Poor's } \\
\text { Compustat }\end{array}$ \\
\hline Unrated & $\begin{array}{l}\text { Equals } 1 \text { if borrower has no S\&P long-term credit rating in the } \\
\text { quarter before loan agreement }\end{array}$ & $\begin{array}{l}\text { Standard \& Poor's } \\
\text { Compustat }\end{array}$ \\
\hline (Log) Total Assets & $\begin{array}{l}\text { (Natural logarithm of) Total Assets in USD; measured one } \\
\text { quarter prior loan agreement }\end{array}$ & $\begin{array}{l}\text { Standard \& Poor's } \\
\text { Compustat }\end{array}$ \\
\hline (Log) Age & (Natural logarithm of) Age since incorporation & $\begin{array}{l}\text { Jay Ritter's } \\
\text { homepage, } \\
\text { Hoover's, } \\
\text { Bloomberg } \\
\text { BusinessWeek }\end{array}$ \\
\hline EBIT/Total Assets & $\begin{array}{l}\text { Calculated as EBIT over total assets, measured one quarter } \\
\text { prior loan agreement }\end{array}$ & $\begin{array}{l}\text { Standard \& Poor's } \\
\text { Compustat }\end{array}$ \\
\hline Market-to-Book & $\begin{array}{l}\text { Calculated as total assets minus book value of equity plus } \\
\text { market value of } \\
\text { equity over total assets; measured one quarter prior loan } \\
\text { agreement }\end{array}$ & $\begin{array}{l}\text { Standard \& Poor's } \\
\text { Compustat }\end{array}$ \\
\hline Public Debt Issuance & $\begin{array}{l}\text { Equals } 1 \text { if borrower publicly issued a debt instrument in the } \\
\text { last } 3 \text { years prior loan agreement. Debt instruments are } \\
\text { classified following the master deal type description from } \\
\text { Thomson SDC }\end{array}$ & $\begin{array}{l}\text { Thomson Reuters } \\
\text { SDC New Issues }\end{array}$ \\
\hline Past Non-Bank Loans & $\begin{array}{l}\text { Equals } 1 \text { if borrower had a non-bank-arranged loan in the last } \\
3 \text { years prior loan agreement }\end{array}$ & $\begin{array}{l}\text { Thomson Reuters } \\
\text { LPC Dealscan }\end{array}$ \\
\hline (Log) Number Prior Loans & $\begin{array}{l}\text { (Natural logarithm of) Number of loans prior current loan } \\
\text { agreement }\end{array}$ & $\begin{array}{l}\text { Thomson Reuters } \\
\text { LPC Dealscan }\end{array}$ \\
\hline Cross-Selling Opportunity & $\begin{array}{l}\text { Equals } 1 \text { if borrower will issue public debt or equity in the } \\
\text { next } 12 \text { months, will syndicate a loan in the next } 12 \text { months or } \\
\text { will announce an M\&A event in the next } 12 \text { months }\end{array}$ & $\begin{array}{l}\text { Thomson Reuters } \\
\text { SDC New Issues, } \\
\text { Thomson Reuters } \\
\text { SDC M\&A, } \\
\text { Thomson Reuters } \\
\text { LPC Dealscan }\end{array}$ \\
\hline
\end{tabular}




\begin{tabular}{lll}
\hline Variables & Description & Data Source \\
\hline KZ index & Following Lamont et al. (2001), the KZ index is calculated as & Compustat \\
& $-1.001909^{*}$ cash flow/property, plant and equipment+ \\
& $0.2826389^{*}$ Tobin's Q + 3.139193*debt/total capital - \\
& $39.3678^{*}$ dividends/property, plant and equipment- \\
& $1.314759^{*}$ cash/property, plant and equipment, while cash \\
& flow is measured as (income before extraordinary items + \\
& depreciation/amortization), Tobin's Q as (liabilities and \\
& stockholders equity + market value of equity-common equity \\
& - deferred taxes)/liabilities and stockholders equity, debt as \\
& (long-term debt + debt in current liabilities) and total capital \\
& as liabilities and stockholders equity.
\end{tabular}

\section{Loan Variables}

AISD

Revolver

Term Loan

(Log) Facility Amount

(Log) Syndicate Size

Syndication

(Log) Maturity

Secured

Sponsored

End of Quarter Loan

Refinancing

Contract Intensity Index

Performance Pricing

General Loan Purpose

Takeover Loan Purpose

LBO Loan Purpose
All-in spread drawn over LIBOR calculated by Dealscan as sum of spread over LIBOR and annual facility fee in basis points

Equals 1 if loan tranche is a revolving credit line

Equals 1 if loan tranche is a term loan $\mathrm{A}, \mathrm{B}$, or higher

(Natural logarithm of) Facility amount in USD

(Natural logarithm of) Number of lenders

Equals 1 if loan is syndication and 0 if loan is financed by the lead arranger only

(Natural logarithm of) Maturity in months

Equals 1 if facility flagged as secured loan

Equals 1 if facility has a loan sponsor, e.g. an PE fund

Equals 1 if facility has been closed in the last 2 weeks of a quarter

Equals 1 if facility is a refinancing of an existing loan, equals 0 if facility is a new loan

Calculated following Bradley and Roberts (2004) as sum of the following dummy variables: asset sweep, debt sweep, equity sweep, secured, more or equal to 2 financial covenants, dividend restrictions. Values are from 0 to 6 with higher values indicating stricter loan agreements

Equals 1 if there is a pricing grid (performance pricing) condition

Equals 1 if loan purpose is capital expenditures, corporate purposes, equipment purchases, purchase of hardware and working capital (similar to Carey et al. (1998))

Equals 1 if loan purpose is acquisition line, $\mathrm{MBO}$, spinoff and takeover (similar to Carey et al. (1998))

Equals 1 if loan purpose is LBO or SBO (similar to Carey et al. (1998))
Thomson Reuters LPC Dealscan

Thomson Reuters LPC Dealscan

Thomson Reuters LPC Dealscan

Thomson Reuters LPC Dealscan

Thomson Reuters LPC Dealscan

Thomson Reuters LPC Dealscan

Thomson Reuters LPC Dealscan

Thomson Reuters LPC Dealscan

Thomson Reuters LPC Dealscan

Thomson Reuters LPC Dealscan

Thomson Reuters LPC Dealscan

Thomson Reuters LPC Dealscan

Thomson Reuters LPC Dealscan Thomson Reuters LPC Dealscan

Thomson Reuters LPC Dealscan

Thomson Reuters LPC Dealscan 


\begin{tabular}{|c|c|c|}
\hline Variables & Description & Data Source \\
\hline $\begin{array}{l}\text { Recapitalization Loan } \\
\text { Purpose }\end{array}$ & $\begin{array}{l}\text { Equals } 1 \text { if loan purpose is debt repayment, debtor-in- } \\
\text { possession, dividend recap, exit financing, IPO related } \\
\text { financing and recapitalizations (similar to Carey et al. (1998)) }\end{array}$ & $\begin{array}{l}\text { Thomson Reuters } \\
\text { LPC Dealscan }\end{array}$ \\
\hline $\begin{array}{l}\text { Miscellaneous Loan } \\
\text { Purpose }\end{array}$ & $\begin{array}{l}\text { Equals } 1 \text { if loan purpose is aircraft finance, CDO, commercial } \\
\text { paper backup, credit enhancement, ESOP, lease finance, } \\
\text { mortgage warehouse, project finance, real estate, securities } \\
\text { purchase, ship finance, stock buyback, trade finance and } \\
\text { other/undisclosed (similar to Carey et al. (1998)) }\end{array}$ & $\begin{array}{l}\text { Thomson Reuters } \\
\text { LPC Dealscan }\end{array}$ \\
\hline Spread & Spread over LIBOR in basis points & $\begin{array}{l}\text { Thomson Reuters } \\
\text { LPC Dealscan }\end{array}$ \\
\hline Facility Fee & Fee paid on the entire committed amount & $\begin{array}{l}\text { Thomson Reuters } \\
\text { LPC Dealscan }\end{array}$ \\
\hline Commitment Fee & Fee paid on the unused part of loan commitment & $\begin{array}{l}\text { Thomson Reuters } \\
\text { LPC Dealscan }\end{array}$ \\
\hline Letter of Credit Fee & Fee paid on drawn amounts on the letter of credit sub-limit & $\begin{array}{l}\text { Thomson Reuters } \\
\text { LPC Dealscan }\end{array}$ \\
\hline Cancellation Fee & Fee paid if the syndicated loan is cancelled before maturity & $\begin{array}{l}\text { Thomson Reuters } \\
\text { LPC Dealscan }\end{array}$ \\
\hline Upfront Fee & Fee paid upon completion of a syndicated loan & $\begin{array}{l}\text { Thomson Reuters } \\
\text { LPC Dealscan }\end{array}$ \\
\hline Utilization Fee & $\begin{array}{l}\text { Fee paid on the entire drawn amount once a certain usage } \\
\text { threshold has been exceeded }\end{array}$ & $\begin{array}{l}\text { Thomson Reuters } \\
\text { LPC Dealscan }\end{array}$ \\
\hline Flexed Dummy & $\begin{array}{l}\text { Dummy that equals } 1 \text { if the pricing of a loan has been } \\
\text { adjusted during the loan syndication, detected through } \\
\text { comments in Dealscan }\end{array}$ & $\begin{array}{l}\text { Thomson Reuters } \\
\text { LPC Dealscan }\end{array}$ \\
\hline Time-on-the-Market & $\begin{array}{l}\text { Duration between launch and start date which measures the } \\
\text { duration of the syndication process }\end{array}$ & $\begin{array}{l}\text { Thomson Reuters } \\
\text { LPC Dealscan }\end{array}$ \\
\hline $\begin{array}{l}\text { Lead Arranger Former } \\
\text { Lead }\end{array}$ & $\begin{array}{l}\text { Equals } 1 \text { if at least one lead arranger has been lead arranger } \\
\text { for this borrower in the past } 5 \text { years of the dataset }\end{array}$ & $\begin{array}{l}\text { Thomson Reuters } \\
\text { LPC Dealscan }\end{array}$ \\
\hline $\begin{array}{l}\text { Lead Arranger Market } \\
\text { Share } \\
\text { Lead Arranger Loan Share }\end{array}$ & $\begin{array}{l}\text { Average lending market share of the lead arrangers in the } \\
\text { year prior loan agreement } \\
\text { Equals the loan share in Dealscan, if not available proxied by } \\
\text { linear distribution across lenders }\end{array}$ & $\begin{array}{l}\text { Thomson Reuters } \\
\text { LPC Dealscan } \\
\text { Thomson Reuters } \\
\text { LPC Dealscan }\end{array}$ \\
\hline $\begin{array}{l}\text { Log Distance Lead } \\
\text { Arrangers vs Borrower }\end{array}$ & $\begin{array}{l}\text { Natural logarithm of the average geographical distance } \\
\text { between lead arrangers (i) and borrower }(\mathrm{j}) \text { following Dass } \\
\text { and Massa }(2011) \text {, calculated as } \\
d_{i, j}=\operatorname{arc} \cos \left(\text { deg }_{\text {latlon }}\right) \times r \\
\text { where } \operatorname{deg}_{\text {latlon }}=\cos \left(\text { lat }_{i}\right) \times \cos \left(\operatorname{lon}_{i}\right) \times \cos \left(\operatorname{lon}_{j}\right)+ \\
\cos \left(\text { lat }_{i}\right) \times \sin \left(\operatorname{lon}_{i}\right) \times \cos \left(\operatorname{lat}_{j}\right) \times \sin \left(\operatorname{lon}_{j}\right)+\sin \left(\text { lat }_{i}\right) \times \\
\sin \left(\text { lat }_{j}\right) \text {, } \\
\text { with lat and lon referring to the latitude and longitude in } \\
\text { radians (converted from degrees by multiplying } \pi / 180), \mathrm{r} \text { is } \\
\text { the radius of Earth in miles }\end{array}$ & $\begin{array}{l}\text { Headquarters: } \\
\text { Thomson Reuters } \\
\text { LPC Dealscan, } \\
\text { Standard \& Poor's } \\
\text { Compustat, } \\
\text { Hoover's, } \\
\text { Bloomberg } \\
\text { BusinessWeek, } \\
\text { Company Websites } \\
\text { Coordinates: U.S. } \\
\text { Board on } \\
\text { Geographic Names, } \\
\text { Worldatlas }\end{array}$ \\
\hline $\begin{array}{l}\text { Potential Participant } \\
\text { Former Lead }\end{array}$ & $\begin{array}{l}\text { Equals } 1 \text { if the potential participant was a former lead during } \\
\text { the last } 3 \text { years for the current borrower }\end{array}$ & $\begin{array}{l}\text { Thomson Reuters } \\
\text { LPC Dealscan }\end{array}$ \\
\hline $\begin{array}{l}\text { Potential Participant } \\
\text { Former Participant }\end{array}$ & $\begin{array}{l}\text { Equals } 1 \text { if the potential participant was a former participant } \\
\text { during the last } 3 \text { years for the current borrower }\end{array}$ & $\begin{array}{l}\text { Thomson Reuters } \\
\text { LPC Dealscan }\end{array}$ \\
\hline
\end{tabular}




\begin{tabular}{|c|c|c|}
\hline Variables & Description & Data Source \\
\hline $\begin{array}{l}\text { Potential Participant Non- } \\
\text { Bank }\end{array}$ & Equals 1 if the potential participant is a non-bank & $\begin{array}{l}\text { Thomson Reuters } \\
\text { LPC Dealscan }\end{array}$ \\
\hline $\begin{array}{l}\text { Log Distance Potential } \\
\text { Participant vs Borrower }\end{array}$ & $\begin{array}{l}\text { Natural logarithm of the distance between the potential } \\
\text { participant and the borrower using the same methodology as } \\
\text { the calculation of the Log Distance Lead Arrangers vs } \\
\text { Borrower }\end{array}$ & $\begin{array}{l}\text { Headquarters: } \\
\text { Thomson Reuters } \\
\text { LPC Dealscan, } \\
\text { Standard \& Poor's } \\
\text { Compustat, } \\
\text { Hoover's, } \\
\text { Bloomberg } \\
\text { BusinessWeek, } \\
\text { Company Websites } \\
\text { Coordinates: U.S. } \\
\text { Board on } \\
\text { Geographic Names, } \\
\text { Worldatlas }\end{array}$ \\
\hline $\begin{array}{l}\text { Was Participant with } \\
\text { Current Lead Last } 3 \text { Years }\end{array}$ & $\begin{array}{l}\text { Equals } 1 \text { if the potential participant was a participant in the } \\
\text { past } 3 \text { years in a syndicate arranged by the current lead } \\
\text { arranger }\end{array}$ & $\begin{array}{l}\text { Thomson Reuters } \\
\text { LPC Dealscan }\end{array}$ \\
\hline $\begin{array}{l}\text { Log Distance Lead } \\
\text { Arranger vs Potential } \\
\text { Participant }\end{array}$ & $\begin{array}{l}\text { Natural logarithm of the distance between the lead arranger } \\
\text { and the potential participant using the same methodology as } \\
\text { the calculation of the Log Distance Lead Arrangers vs } \\
\text { Borrower }\end{array}$ & $\begin{array}{l}\text { Headquarters: } \\
\text { Thomson Reuters } \\
\text { LPC Dealscan, } \\
\text { Standard \& Poor's } \\
\text { Compustat, } \\
\text { Hoover's, } \\
\text { Bloomberg } \\
\text { BusinessWeek, } \\
\text { Company Websites } \\
\text { Coordinates: U.S. } \\
\text { Board on } \\
\text { Geographic Names, } \\
\text { Worldatlas }\end{array}$ \\
\hline Non-Bank-Led & Equals 1 if the lead arranger(s) is (are) non-banks & $\begin{array}{l}\text { Thomson Reuters } \\
\text { LPC Dealscan }\end{array}$ \\
\hline $\begin{array}{l}\text { Bank-Led With Non-Bank } \\
\text { Participants }\end{array}$ & $\begin{array}{l}\text { Equals } 1 \text { if the lead arranger(s) is (are) banks and there is at } \\
\text { least one non-bank as participant }\end{array}$ & $\begin{array}{l}\text { Thomson Reuters } \\
\text { LPC Dealscan }\end{array}$ \\
\hline Relationship Score & $\begin{array}{l}\text { Calculated as number of facilities between lead } i \text { and } \\
\text { participant } j \text { averaged through all participants in this facility } \\
\text { and divided by the number of facilities led by } i \text { in the past } 3 \\
\text { years following the methodology in Lim et al. (2014) }\end{array}$ & $\begin{array}{l}\text { Thomson Reuters } \\
\text { LPC Dealscan }\end{array}$ \\
\hline $\begin{array}{l}\text { Lead Arranger Credit } \\
\text { Rating }\end{array}$ & $\begin{array}{l}\text { Equals the lead arranger's long-term S\&P credit rating in the } \\
\text { month prior loan agreement; if no rating available, rating } \\
\text { category "not rated" has been assigned }\end{array}$ & $\begin{array}{l}\text { Standard \& Poor's } \\
\text { Compustat, } \\
\text { Standard \& Poor's } \\
\text { Global Credit } \\
\text { Portal }\end{array}$ \\
\hline Default During Loan & $\begin{array}{l}\text { Equals } 1 \text { if company receives an S\&P long-term credit rating } \\
\text { of "D" or "SD" while loan is active }\end{array}$ & $\begin{array}{l}\text { Standard \& Poor's } \\
\text { Compustat, } \\
\text { Standard \& Poor's } \\
\text { Global Credit } \\
\text { Portal }\end{array}$ \\
\hline
\end{tabular}




\begin{tabular}{|c|c|c|}
\hline Variables & Description & Data Source \\
\hline $\begin{array}{l}\text { Default One Year After } \\
\text { Loan Maturity }\end{array}$ & $\begin{array}{l}\text { Equals } 1 \text { if company receives an S\&P long-term credit rating } \\
\text { of "D" or "SD" within one year after loan maturity }\end{array}$ & $\begin{array}{l}\text { Standard \& Poor's } \\
\text { Compustat, } \\
\text { Standard \& Poor's } \\
\text { Global Credit } \\
\text { Portal }\end{array}$ \\
\hline $\begin{array}{l}\text { Default After Loan } \\
\text { Maturity }\end{array}$ & $\begin{array}{l}\text { Equals } 1 \text { if company receives an S\&P long-term credit rating } \\
\text { of "D" or "SD" after loan maturity }\end{array}$ & $\begin{array}{l}\text { Standard \& Poor's } \\
\text { Compustat, } \\
\text { Standard \& Poor's } \\
\text { Global Credit } \\
\text { Portal }\end{array}$ \\
\hline Total Cost of Borrowing & $\begin{array}{l}\text { Following Berg et al. (2015), I use the following formula for } \\
\text { the calculations. } \\
\text { Total Cost of Borrowing = Upfront fee/Loan Maturity in years } \\
+ \text { Facility fee + (1-Probability Drawn Down) } \times \text { Commitment } \\
\text { Fee + PDD x Spread + PDD x LC-Limit x (Letter of Credit fee } \\
\text { - Spread) + PDD x } \\
\text { Prob(Utilization }>\text { UtilizationThreshold I Usage }>0) \times \\
\text { Utilization fee + Prob(Cancellation) } \times \text { Cancellation fee } \\
\text { The calibration of the probabilities have been taken from their } \\
\text { paper }\end{array}$ & $\begin{array}{l}\text { Thomson Reuters } \\
\text { LPC Dealscan }\end{array}$ \\
\hline \multicolumn{3}{|l|}{ Other Control Variables } \\
\hline Total HHI & $\begin{array}{l}\text { Country-wide competition measured as Herfindahl- } \\
\text { Hirschman index of lending market share for one year prior } \\
\text { loan agreement based on market shares in percentage points }\end{array}$ & $\begin{array}{l}\text { Thomson Reuters } \\
\text { LPC Dealscan }\end{array}$ \\
\hline Tightening Standards & $\begin{array}{l}\text { Equals the net percentage points of domestic and foreign } \\
\text { commercial banks tightening their standards to U.S. } \\
\text { borrowers of all sizes, positive values are associated with } \\
\text { tighter loan standards }\end{array}$ & $\begin{array}{l}\text { Fed Loan Officer } \\
\text { Survey }\end{array}$ \\
\hline Number Main Offices & $\begin{array}{l}\text { Number of major branches (called main offices) in the county } \\
\text { of the borrower }\end{array}$ & FDIC \\
\hline Local HHI & $\begin{array}{l}\text { County-wide competition measured as Herfindahl- } \\
\text { Hirschman index of deposits based on deposit market shares } \\
\text { in percentage points }\end{array}$ & FDIC \\
\hline
\end{tabular}




\section{Table 2}

Descriptive Statistics

Panel A contains descriptive statistics including Student's t-tests of the difference in means between non-banks and banks. Panel B list key variables to compare the funding of the different major lead arranger types based on my data set if public information is available and based on other papers for mostly private companies. Definitions of all variables can be found in Table $1 .{ }^{* *},{ }^{* *}$, and ${ }^{*}$ correspond to the statistical significance levels of $1 \%, 5 \%$ and $10 \%$.

Panel A: Descriptive statistics

\begin{tabular}{|c|c|c|c|c|c|c|c|c|c|}
\hline & \multicolumn{3}{|c|}{ Non-Bank Lead Arrangers (1) } & \multicolumn{3}{|c|}{ Bank Lead Arrangers (2) } & \multicolumn{3}{|c|}{ Difference (1) - (2) } \\
\hline & Mean & SD & Observations & Mean & SD & Observations & Diff. & t-Value & Observations \\
\hline \multicolumn{10}{|l|}{ Borrower Characteristics } \\
\hline KZ Index & -1.52 & 16.24 & 561 & -2.06 & 29.06 & 8,939 & 0.53 & 0.43 & 9,500 \\
\hline Z-Score & 2.13 & 2.01 & 746 & 2.09 & 1.68 & 12,101 & 0.04 & 0.66 & 12,847 \\
\hline Leverage & 0.31 & 0.28 & 746 & 0.35 & 0.31 & 12,101 & $-0.04^{* * *}$ & -3.91 & 12,847 \\
\hline Unrated & 0.72 & 0.45 & 746 & 0.54 & 0.50 & 12,101 & $0.18^{* * *}$ & 9.70 & 12,847 \\
\hline Total Assets (\$M) & 954.06 & $3,240.03$ & 746 & $2,125.97$ & $6,046.81$ & 12,101 & $-1,171.91^{* * *}$ & -5.25 & 12,847 \\
\hline Age & 28.11 & 31.43 & 746 & 32.99 & 34.00 & 12,101 & $-4.88^{* * *}$ & -3.82 & 12,847 \\
\hline EBIT/Total Assets & 0.04 & 0.11 & 746 & 0.06 & 0.13 & 12,101 & $-0.02^{* * *}$ & -5.36 & 12,847 \\
\hline Market-to-Book & 1.29 & 1.27 & 746 & 1.22 & 1.01 & 12,101 & $0.07^{*}$ & 1.88 & 12,847 \\
\hline Public Debt Issuance & 0.07 & 0.25 & 746 & 0.16 & 0.36 & 12,101 & $-0.09^{* * *}$ & -6.48 & 12,847 \\
\hline Past Non-Bank Loans & 0.22 & 0.42 & 746 & 0.02 & 0.12 & 12,101 & $0.21^{* * *}$ & 35.36 & 12,847 \\
\hline Number Prior Loans & 3.72 & 4.38 & 746 & 5.22 & 5.62 & 12,101 & $-1.50^{* * *}$ & -7.17 & 12,847 \\
\hline Cross-Selling Opportunity & 0.45 & 0.50 & 746 & 0.55 & 0.50 & 12,101 & $-0.09^{* * *}$ & -5.04 & 12,847 \\
\hline \multicolumn{10}{|l|}{ Loan Characteristics } \\
\hline AISD & 376.16 & 189.02 & 746 & 274.09 & 111.42 & 12,101 & $102.07^{* * *}$ & 23.06 & 12,847 \\
\hline Revolver & 0.57 & 0.50 & 746 & 0.59 & 0.49 & 12,101 & -0.02 & -0.74 & 12,847 \\
\hline Facility Amount (\$M) & 74.45 & 147.44 & 746 & 205.91 & 429.12 & 12,101 & $-131.46^{* * *}$ & -8.34 & 12,847 \\
\hline Syndicate Size & 2.94 & 2.60 & 746 & 6.71 & 8.46 & 12,101 & $-3.77^{* * *}$ & -12.14 & 12,847 \\
\hline Syndication & 0.58 & 0.49 & 746 & 0.79 & 0.41 & 12,101 & $-0.21^{* * *}$ & -13.40 & 12,847 \\
\hline Maturity & 48.40 & 17.36 & 746 & 51.64 & 22.25 & 12,101 & $-3.24^{* * *}$ & -3.90 & 12,847 \\
\hline Secured & 0.85 & 0.36 & 746 & 0.78 & 0.41 & 12,101 & $0.07^{* * *}$ & 4.23 & 12,847 \\
\hline Sponsored & 0.18 & 0.39 & 746 & 0.18 & 0.39 & 12,101 & 0.00 & 0.06 & 12,847 \\
\hline End of Quarter Loan & 0.28 & 0.45 & 746 & 0.24 & 0.43 & 12,101 & $0.04^{* *}$ & 2.33 & 12,847 \\
\hline Refinancing & 0.65 & 0.48 & 746 & 0.71 & 0.45 & 12,101 & $-0.06^{* * *}$ & -3.48 & 12,847 \\
\hline
\end{tabular}




\begin{tabular}{|c|c|c|c|c|c|c|c|c|c|}
\hline Contract Intensity Index & 3.16 & 1.85 & 746 & 2.96 & 1.91 & 12,101 & $0.21^{* * *}$ & 2.87 & 12,847 \\
\hline Performance Pricing & 0.33 & 0.47 & 746 & 0.50 & 0.50 & 12,101 & $-0.17^{* * *}$ & -8.81 & 12,847 \\
\hline General Loan Purpose & 0.49 & 0.02 & 746 & 0.50 & 0.00 & 12,101 & -0.01 & -0.22 & 12,847 \\
\hline Takeover Loan Purpose & 0.22 & 0.02 & 746 & 0.22 & 0.00 & 12,101 & 0.00 & 0.06 & 12,847 \\
\hline LBO Loan Purpose & 0.04 & 0.01 & 746 & 0.04 & 0.00 & 12,101 & 0.00 & -1.03 & 12,847 \\
\hline Recapitalization Loan Purpose & 0.25 & 0.02 & 746 & 0.22 & 0.00 & 12,101 & $0.03^{*}$ & 1.91 & 12,847 \\
\hline Miscellaneous Loan Purpose & 0.00 & 0.00 & 746 & 0.02 & 0.00 & 12,101 & $-0.02^{* * *}$ & -3.51 & 12,847 \\
\hline Z-Score at Loan Origination (Year 0) & 1.84 & 2.01 & 746 & 1.90 & 1.72 & 12,101 & -0.06 & -0.89 & 12,847 \\
\hline Z-Score at Year 1 & 1.96 & 2.02 & 610 & 1.98 & 1.93 & 10,673 & -0.01 & -0.16 & 11,283 \\
\hline Z-Score at Year 2 & 1.86 & 1.86 & 521 & 2.00 & 2.03 & 9,304 & -0.14 & 1.55 & 9,825 \\
\hline Z-Score at Year 3 & 2.06 & 2.15 & 456 & 2.03 & 2.08 & 8,258 & 0.03 & 0.29 & 8,714 \\
\hline Default During Loan & 0.08 & 0.27 & 746 & 0.06 & 0.24 & 12,101 & $0.02^{* *}$ & 2.12 & 12,847 \\
\hline Default Within One Year After Loan & 0.01 & 0.07 & 746 & 0.01 & 0.09 & 12,101 & 0.00 & -0.71 & 12,847 \\
\hline Default After Loan & 0.02 & 0.14 & 746 & 0.04 & 0.19 & 12,101 & $-0.02^{* *}$ & -2.40 & 12,847 \\
\hline \multicolumn{10}{|l|}{ Lead Arranger Characteristics } \\
\hline Lead Arranger Former Lead & 0.25 & 0.43 & 746 & 0.41 & 0.49 & 12,101 & $-0.16^{* * *}$ & -8.65 & 12,847 \\
\hline Lead Arranger Market Share & 2.07 & 1.61 & 746 & 7.20 & 5.05 & 12,101 & $-5.12^{* * *}$ & -27.63 & 12,847 \\
\hline $\begin{array}{l}\text { Distance Lead Arrangers vs Borrower } \\
\text { (in miles) }\end{array}$ & 916.79 & 783.90 & 746 & $1,135.71$ & $1,257.14$ & 12,101 & $-218.92^{* * *}$ & -4.70 & 12,847 \\
\hline Relationship Score & 0.04 & 0.06 & 746 & 0.07 & 0.06 & 12,101 & $-0.03^{* * *}$ & -12.86 & 12,847 \\
\hline Flexed Dummy & 0.00 & 0.06 & 746 & 0.01 & 0.11 & 12,101 & $-0.01^{*}$ & -1.85 & 12,847 \\
\hline Time-on-the-Market & 26.89 & 13.82 & 28 & 31.59 & 36.43 & 1,738 & -4.70 & 0.68 & 1,766 \\
\hline \multicolumn{10}{|l|}{ Other Control Variables } \\
\hline Total HHI & 0.47 & 0.07 & 746 & 0.47 & 0.07 & 12,101 & $-0.01^{* * *}$ & -3.03 & 12,847 \\
\hline Tightening Standards & 10.14 & 23.33 & 746 & 11.57 & 23.55 & 12,101 & -1.43 & -1.61 & 12,847 \\
\hline Number Main Offices & 27.56 & 32.29 & 746 & 25.17 & 31.05 & 12,101 & $2.39^{* *}$ & 2.03 & 12,847 \\
\hline Local HHI & 0.06 & 0.08 & 746 & 0.06 & 0.09 & 12,101 & 0.00 & -1.22 & 12,847 \\
\hline
\end{tabular}


Panel B: Differences in financing

\begin{tabular}{lccc|c}
\hline Lead Arranger Type & Mean Equity Ratio & Mean Leverage Ratio & Mean Long-Term Debt Ratio & Source \\
\hline Banks & 0.09 & 0.91 & 0.12 & Own Data Set \\
\hdashline Finance Companies & 0.16 & 0.84 & 0.51 & Own Data Set \\
Hedge Funds & 0.74 & 0.26 & low & Ang et al. (2011) \\
Private Equity Funds & 0.25 & 0.75 & high $^{*}$ & Axelson et al. (2013) \\
\hline
\end{tabular}

*Following the papers from which the data has been taken 


\section{Table 3}

Specific Industry Expertise

This table shows the 20 industries with the highest number of non-bank-arranged loans and their respective rank for bank-arranged loans

\begin{tabular}{|c|c|c|c|}
\hline $\begin{array}{c}\text { SIC } \\
\text { Code }\end{array}$ & $\begin{array}{c}\text { Rank Non-Bank } \\
\text { Lead Arrangers (1) }\end{array}$ & $\begin{array}{c}\text { Rank Bank } \\
\text { Lead Arrangers } \\
(2)\end{array}$ & Industry Description \\
\hline 5812 & 1 & 2 & Eating Places \\
\hline 7363 & 2 & 32 & Help Supply Services (e.g. manpower pools, etc.) \\
\hline 2835 & 3 & 133 & In Vitro and In Vivo Diagnostic Substances \\
\hline 2330 & 4 & 185 & Women's, Misses', and Juniors' Outerwear \\
\hline 4813 & 5 & 4 & Telephone Communications, Except Radiotelephone \\
\hline 7372 & 6 & 6 & Prepackaged Software \\
\hline 3714 & 7 & 5 & Motor Vehicle Parts and Accessories \\
\hline 3081 & 8 & 279 & Unsupported Plastics Film and Sheet \\
\hline 4512 & 9 & 26 & Air Transportation, Scheduled \\
\hline 4899 & 10 & 8 & Communications Services, Not Elsewhere Classified \\
\hline 5045 & 11 & 124 & Computers and Computer Peripheral Equipment and Software \\
\hline 1381 & 12 & 34 & Drilling Oil and Gas Wells \\
\hline 3540 & 13 & 116 & Metalworking Machinery and Equipment \\
\hline 3949 & 14 & 96 & Sporting and Athletic Goods, Not Elsewhere Classified \\
\hline 7374 & 15 & 33 & Computer Processing and Data Preparation and Processing Services \\
\hline 1389 & 16 & 29 & Oil and Gas Field Services, Not Elsewhere Classified \\
\hline 2300 & 17 & 39 & Apparel and other Finished Products Made from Fabrics and Similar Materials \\
\hline 3060 & 18 & 313 & Fabricated Rubber Products, not elsewhere classified \\
\hline 3140 & 19 & 174 & Footwear, Except Rubber \\
\hline 4833 & 20 & 16 & Television Broadcasting Stations \\
\hline
\end{tabular}




\section{Table 4}

Choice of Lead Arranger

This table presents the coefficient estimates of a probit regression with a dummy equaling 1 for non-bank-arranged loans as dependent variable and 0 for bank-arranged loans. Definitions of all variables can be found in Table 1 . Other control variables contain the variables Total HHI, Tightening Standards, Number Main Offices and Local HHI. Fixed effects contain time, industry, loan purpose and loan type fixed effects. Standard errors are clustered by borrower. ${ }^{* *},{ }^{* *}$, and ${ }^{*}$ correspond to the statistical significance levels of $1 \%, 5 \%$ and $10 \%$, respectively.

\begin{tabular}{|c|c|c|}
\hline \multirow[b]{2}{*}{ Variables } & \multicolumn{2}{|c|}{$\begin{array}{c}\text { Non-Bank Lead Arranger vs } \\
\text { Bank Lead Arranger }\end{array}$} \\
\hline & Coef. & Se. \\
\hline \multicolumn{3}{|l|}{ Borrower Variables } \\
\hline Z-Score & -0.03 & $(0.03)$ \\
\hline Leverage & -0.03 & $(0.11)$ \\
\hline Unrated & 0.09 & $(0.08)$ \\
\hline Log Total Assets & $-0.09 * * *$ & $(0.02)$ \\
\hline Log Age & -0.03 & $(0.04)$ \\
\hline EBIT/Total Assets & -0.26 & $(0.20)$ \\
\hline Market-to-Book & 0.00 & $(0.03)$ \\
\hline Public Debt Issuance & $-0.37^{* * *}$ & $(0.10)$ \\
\hline Past Non-Bank Loans & $1.72^{* * *}$ & $(0.12)$ \\
\hline Log Number Prior Loans & $-0.16^{* * *}$ & $(0.04)$ \\
\hline Cross-Selling Opportunity & $-0.13^{* *}$ & $(0.05)$ \\
\hline \multicolumn{3}{|l|}{ Loan Variables } \\
\hline Log Maturity & 0.04 & $(0.05)$ \\
\hline Secured & $0.16^{* *}$ & $(0.08)$ \\
\hline Sponsored & 0.09 & $(0.10)$ \\
\hline End of Quarter Loan & 0.10 & $(0.06)$ \\
\hline Refinancing & $-0.15^{* *}$ & $(0.06)$ \\
\hline Other Control Variables E Fixed Effects & \multicolumn{2}{|c|}{ Yes } \\
\hline Observations & \multicolumn{2}{|c|}{12,847} \\
\hline Pseudo R-squared & \multicolumn{2}{|c|}{0.16} \\
\hline
\end{tabular}




\section{Table 5}

Choice of Syndication vs Sole-Lender Loan

This table presents the probit regression coefficient estimates of the syndication vs sole-lender decision. Definitions of all variables can be found in Table 1 . The dependent variable is 1 for syndicated loans and 0 otherwise. Other control variables contain the variables Total HHI, Tightening Standards, Number Main Offices and Local HHI. Fixed effects contain time, industry, loan purpose and loan type fixed effects. Standard errors are clustered by borrower. ${ }^{* *},{ }^{* *}$, and ${ }^{*}$ correspond to the statistical significance levels of $1 \%, 5 \%$ and $10 \%$, respectively.

\begin{tabular}{|c|c|c|}
\hline \multirow[b]{2}{*}{ Variables } & \multicolumn{2}{|c|}{ Syndication } \\
\hline & Coef. & Se. \\
\hline \multicolumn{3}{|l|}{ Base Effect - Bank Lead Arrangers } \\
\hline \multicolumn{3}{|l|}{ Borrower Variables } \\
\hline Z-Score & 0.00 & $(0.02)$ \\
\hline Leverage & $0.21^{*}$ & $(0.11)$ \\
\hline Unrated & 0.03 & $(0.06)$ \\
\hline Log Total Assets & $0.42^{* * *}$ & $(0.03)$ \\
\hline Log Age & 0.02 & $(0.02)$ \\
\hline EBIT/Total Assets & $1.27^{* * *}$ & $(0.23)$ \\
\hline Market-to-Book & 0.00 & $(0.02)$ \\
\hline Public Debt Issuance & $0.22^{* * *}$ & $(0.07)$ \\
\hline Past Non-Bank Loans & 0.03 & $(0.16)$ \\
\hline Log Number Prior Loans & $0.10^{* * *}$ & $(0.03)$ \\
\hline Cross-Selling Opportunity & $0.09^{* *}$ & $(0.04)$ \\
\hline \multicolumn{3}{|l|}{ Loan Variables } \\
\hline Log Maturity & $0.42^{* * *}$ & $(0.04)$ \\
\hline Secured & -0.08 & $(0.06)$ \\
\hline Sponsored & $0.44^{* * *}$ & $(0.10)$ \\
\hline End of Quarter Loan & 0.01 & $(0.05)$ \\
\hline Refinancing & $0.35^{* * *}$ & $(0.05)$ \\
\hline Lead Arranger Former Lead & $0.15^{* * *}$ & $(0.05)$ \\
\hline Lead Arranger Market Share & $0.02^{* * *}$ & $(0.00)$ \\
\hline Log Distance Lead Arrangers vs Borrower & -0.01 & $(0.01)$ \\
\hline \multicolumn{3}{|l|}{ Specific Intercept } \\
\hline Non-Bank-Led & 1.63 & $(1.16)$ \\
\hline \multicolumn{3}{|l|}{ Interaction Effect - Non-Bank Lead Arrangers } \\
\hline \multicolumn{3}{|l|}{ Interacted Borrower Variables } \\
\hline Interacted Z-Score & 0.00 & $(0.05)$ \\
\hline Interacted Leverage & 0.00 & $(0.36)$ \\
\hline Interacted Unrated & 0.03 & $(0.22)$ \\
\hline Interacted Log Total Assets & $-0.19^{* *}$ & $(0.08)$ \\
\hline Interacted Log Age & 0.04 & $(0.09)$ \\
\hline Interacted EBIT/Total Assets & $-2.01^{* * *}$ & $(0.74)$ \\
\hline
\end{tabular}




\begin{tabular}{lcc} 
Table 5 - continued & & \\
Interacted Market-to-Book & -0.02 & $(0.07)$ \\
Interacted Public Debt Issuance & $-0.64^{* *}$ & $(0.33)$ \\
Interacted Past Non-Bank Loans & 0.13 & $(0.34)$ \\
Interacted Log Number Prior Loans & 0.04 & $(0.10)$ \\
Interacted Cross-Selling Opportunity & 0.03 & $(0.15)$ \\
Interacted Loan Variables & & \\
Interacted Log Maturity & -0.01 & $(0.15)$ \\
Interacted Secured & -0.23 & $(0.26)$ \\
Interacted Sponsored & 0.41 & $(0.29)$ \\
Interacted End of Quarter Loan & 0.11 & $(0.16)$ \\
Interacted Refinancing & $-0.52^{* * *}$ & $(0.17)$ \\
Interacted Lead Arranger Former Lead & -0.02 & $(0.30)$ \\
Interacted Lead Arranger Market Share & 0.00 & $(0.05)$ \\
Interacted Log Distance Lead Arrangers vs Borrower & -0.01 & \\
Other Control Variables \& Fixed Effects & \multicolumn{2}{c}{ Yes } \\
\hline Observations & \multicolumn{2}{c}{12,847} \\
Pseudo R-squared & \multicolumn{2}{c}{0.34} \\
\hline
\end{tabular}




\section{Table 6}

Choice of Concrete Participants

This table presents a probit regression of the choice of concrete participants for all loans that have been syndicated. Definitions of all variables can be found in Table 1. The dependent variable is 1 for all participants in a loan and 0 for all potential participants. Potential participants are measured similarly to Sufi (2007) as all participants that have been active in the current year and represent more than $0.5 \%$ of all participants. Borrower variables, loan variables and other control variables contain the variables used in Table 5. Fixed effects contain time, industry, loan purpose and loan type fixed effects. Standard errors are clustered by borrower. ${ }^{* * *},{ }^{* *}$, and ${ }^{*}$ correspond to the statistical significance levels of $1 \%, 5 \%$ and $10 \%$, respectively.

\begin{tabular}{|c|c|c|}
\hline \multirow[b]{2}{*}{ Variables } & \multicolumn{2}{|c|}{ Potential Participant } \\
\hline & Coef. & Se. \\
\hline \multicolumn{3}{|l|}{ Base Effect - Bank Lead Arrangers } \\
\hline Potential Participant Former Lead & -0.04 & $(0.03)$ \\
\hline Potential Participant Former Participant & $0.67^{* * *}$ & $(0.02)$ \\
\hline Potential Participant Non-Bank & $0.12^{* * *}$ & $(0.02)$ \\
\hline Log Distance Potential Participant vs Borrower & $-0.05^{* * *}$ & $(0.00)$ \\
\hline Was Participant with Current Lead Last 3 Years & $0.12^{* * *}$ & $(0.02)$ \\
\hline Log Distance Lead Arranger vs Potential Participant & $0.01^{* * *}$ & $(0.00)$ \\
\hline \multicolumn{3}{|l|}{ Specific Intercept } \\
\hline Non-Bank-Led & -0.16 & $(0.14)$ \\
\hline \multicolumn{3}{|l|}{ Interaction Effect - Non-Bank Lead Arrangers } \\
\hline Interacted Potential Participant Former Lead & 0.23 & $(0.14)$ \\
\hline Interacted Potential Participant Former Participant & -0.13 & $(0.08)$ \\
\hline Interacted Potential Participant Non-Bank & $0.30^{* *}$ & $(0.12)$ \\
\hline Interacted Log Distance Potential Participant vs Borrower & $-0.05^{* *}$ & $(0.02)$ \\
\hline Interacted Was Participant with Current Lead Last 3 Years & $0.23^{* * *}$ & $(0.08)$ \\
\hline Interacted Log Distance Lead Arranger vs Potential Participant & 0.02 & $(0.02)$ \\
\hline Borrower Variables & \multicolumn{2}{|c|}{ Yes } \\
\hline Loan Variables & \multicolumn{2}{|c|}{ Yes } \\
\hline Other Control Variables \& Fixed Effects & \multicolumn{2}{|c|}{ Yes } \\
\hline Observations & \multicolumn{2}{|c|}{437,760} \\
\hline Pseudo R-squared & \multicolumn{2}{|c|}{0.07} \\
\hline
\end{tabular}




\section{Table 7}

Differences in Loan Pricing

This table presents an OLS regression testing the pricing differences among bank-arranged and non-bank-arranged loans. Definitions of all variables can be found in Table 1. Other control variables contain the variables Total HHI, Tightening Standards, Number Main Offices and Local HHI. Fixed effects contain time, industry, loan purpose and loan type fixed effects. Standard errors are clustered by borrower. ${ }^{* *},{ }^{* *}$, and ${ }^{*}$ correspond to the statistical significance levels of $1 \%, 5 \%$ and $10 \%$, respectively.

\begin{tabular}{|c|c|c|}
\hline \multirow[b]{2}{*}{ Variables } & \multicolumn{2}{|c|}{ AISD } \\
\hline & Coef. & Se. \\
\hline \multicolumn{3}{|l|}{ Specific Intercept } \\
\hline Non-Bank-Led & $105.32^{* * *}$ & (12.18) \\
\hline \multicolumn{3}{|l|}{ Borrower Variables } \\
\hline Z-Score & $-7.84^{* * *}$ & $(1.27)$ \\
\hline Leverage & 9.00 & (6.19) \\
\hline Unrated & -2.85 & (3.73) \\
\hline Log Total Assets & 1.84 & (1.33) \\
\hline Log Age & $-2.57^{* *}$ & $(1.30)$ \\
\hline EBIT/Total Assets & $-55.41^{* * *}$ & $(19.14)$ \\
\hline Market-to-Book & 0.45 & (1.49) \\
\hline Public Debt Issuance & 0.42 & (3.53) \\
\hline Past Non-Bank Loans & $22.38^{* *}$ & (9.59) \\
\hline Log Number Prior Loans & 1.51 & $(1.71)$ \\
\hline Cross-Selling Opportunity & -1.45 & (2.29) \\
\hline \multicolumn{3}{|l|}{ Loan Variables } \\
\hline Log Facility Amount & $-6.79^{* * *}$ & (1.16) \\
\hline Log Syndicate Size & $-18.44^{* * *}$ & $(2.35)$ \\
\hline Log Maturity & $-12.18^{* * *}$ & (2.76) \\
\hline Secured & $15.27^{* * *}$ & (3.78) \\
\hline Sponsored & $11.94^{* * *}$ & (3.57) \\
\hline End of Quarter Loan & -0.77 & $(2.51)$ \\
\hline Refinancing & $-10.86^{* * *}$ & $(2.87)$ \\
\hline Lead Arranger Former Lead & $-6.86^{* * *}$ & $(2.62)$ \\
\hline Lead Arranger Market Share & $-0.56^{* *}$ & $(0.23)$ \\
\hline Log Distance Lead Arrangers vs Borrower & 0.99 & $(0.73)$ \\
\hline Contract Intensity Index & $8.35^{* * *}$ & $(0.97)$ \\
\hline Performance Pricing & $-40.19^{* * *}$ & (2.46) \\
\hline Relationship Score & $-76.90^{* * *}$ & $(23.21)$ \\
\hline Syndication & $33.52^{* * *}$ & $(4.55)$ \\
\hline Other Control Variables \& Fixed Effects & \multicolumn{2}{|c|}{ Yes } \\
\hline Observations & \multicolumn{2}{|c|}{12,847} \\
\hline Adjusted R-squared & \multicolumn{2}{|c|}{0.33} \\
\hline
\end{tabular}




\section{Table 8}

Drivers of Differences in Loan Pricing

This table presents an OLS regression testing the drivers of pricing differences between non-bank-arranged loans and bankled by adding interactions of variables potentially driving the markup with the non-bank-led dummy. Definitions of all variables can be found in Table 1. Other control variables contain the variables Total HHI, Tightening Standards, Number Main Offices and Local HHI. Fixed effects contain time, industry, loan purpose and loan type fixed effects. Standard errors are clustered by borrower. ${ }^{* * *}, * *$, and ${ }^{*}$ correspond to the statistical significance levels of $1 \%, 5 \%$ and $10 \%$, respectively.

\begin{tabular}{|c|c|c|}
\hline \multirow[b]{2}{*}{ Variables } & \multicolumn{2}{|c|}{ AISD } \\
\hline & Coef. & Se. \\
\hline \multicolumn{3}{|l|}{ Specific Intercept } \\
\hline Non-Bank-Led & $273.79^{* * *}$ & $(78.77)$ \\
\hline \multicolumn{3}{|l|}{ Interactions with Non-Bank-Led Dummy } \\
\hline Interacted Cross-Selling Opportunity & 8.24 & $(12.99)$ \\
\hline Interacted Unrated & $35.15^{* *}$ & $(14.82)$ \\
\hline Interacted Total Assets & 10.03 & $(6.14)$ \\
\hline Interacted Market-to-Book & $18.57^{* *}$ & $(7.58)$ \\
\hline Interacted Z-Score & -5.29 & $(5.33)$ \\
\hline Interacted Leverage & $-53.46^{*}$ & $(27.40)$ \\
\hline Interacted Relationship Score & $-309.32^{* * *}$ & $(107.94)$ \\
\hline Interacted Lead Arranger Market Share & $-27.85^{* * *}$ & $(7.42)$ \\
\hline Interacted Performance Pricing & $-36.45^{* * *}$ & $(10.84)$ \\
\hline Interacted Total HHI & $-0.42^{* * *}$ & $(0.11)$ \\
\hline Interacted Tightening Standards & $-0.72^{* *}$ & $(0.31)$ \\
\hline \multicolumn{3}{|l|}{ Borrower Variables } \\
\hline Z-Score & $-6.97^{* * *}$ & $(1.20)$ \\
\hline Leverage & $13.65^{* *}$ & $(6.04)$ \\
\hline Unrated & -5.34 & $(3.81)$ \\
\hline Log Total Assets & 1.15 & $(1.33)$ \\
\hline Log Age & $-2.43^{*}$ & $(1.28)$ \\
\hline EBIT/Total Assets & $-57.87^{* * *}$ & $(17.84)$ \\
\hline Market-to-Book & -2.24 & $(1.37)$ \\
\hline Public Debt Issuance & -0.05 & $(3.52)$ \\
\hline Past Non-Bank Loans & $21.04^{* *}$ & $(9.54)$ \\
\hline Log Number Prior Loans & 1.27 & $(1.69)$ \\
\hline Cross-Selling Opportunity & -1.67 & $(2.27)$ \\
\hline \multicolumn{3}{|l|}{ Loan Variables } \\
\hline Log Facility Amount & $-6.19^{* * *}$ & $(1.16)$ \\
\hline Log Syndicate Size & $-18.65^{* * *}$ & $(2.33)$ \\
\hline Log Maturity & $-12.68^{* * *}$ & $(2.74)$ \\
\hline
\end{tabular}


Table 8 - continued

\begin{tabular}{lcc}
\hline Secured & $15.17^{* * *}$ & $(3.71)$ \\
Sponsored & $10.50^{* * *}$ & $(3.60)$ \\
End of Quarter Loan & -0.53 & $(2.50)$ \\
Refinancing & $-10.44^{* * *}$ & $(2.85)$ \\
Lead Arranger Former Lead & $-6.11^{* *}$ & $(2.60)$ \\
Lead Arranger Market Share & $-0.62^{* * *}$ & $(0.23)$ \\
Log Distance Lead Arrangers vs Borrower & 1.13 & $(0.70)$ \\
Contract Intensity Index & $8.35^{* * *}$ & $(0.96)$ \\
Performance Pricing & $-37.74^{* * *}$ & $(2.43)$ \\
Relationship Score & $-66.69^{* * *}$ & $(23.29)$ \\
Syndication & $33.30^{* * *}$ & $(4.43)$ \\
Other Control Variables \& Fixed Effects & \multicolumn{2}{c}{ Yes } \\
Observations & \multicolumn{2}{c}{12,847} \\
Adjusted R-squared & \multicolumn{2}{c}{0.34} \\
\hline
\end{tabular}




\section{Table 9}

Choice of Lead Arranger - Robustness Test

This table presents the coefficient estimates of a probit regression with a dummy equaling 1 for non-bank-arranged loans as dependent variable and 0 for bank-arranged loans. In addition to Table 4 , ta financial constraint indices has been added to the model. Definitions of all variables can be found in Table 1. Other control variables contain the variables Total HHI, Tightening Standards, Number Main Offices and Local HHI. Fixed effects contain time, industry, loan purpose and loan type fixed effects. Standard errors are clustered by borrower. ${ }^{* *},{ }^{* *}$, and ${ }^{*}$ correspond to the statistical significance levels of $1 \%, 5 \%$ and $10 \%$, respectively.

\begin{tabular}{|c|c|c|}
\hline \multirow[b]{2}{*}{ Variables } & \multicolumn{2}{|c|}{$\begin{array}{l}\text { Non-Bank Lead Arranger vs } \\
\text { Bank Lead Arranger }\end{array}$} \\
\hline & Coef. & Se. \\
\hline \multicolumn{3}{|l|}{ Borrower Variables } \\
\hline KZ Index & 0.00 & $(0.00)$ \\
\hline Z-Score & -0.01 & $(0.03)$ \\
\hline Leverage & 0.07 & $(0.17)$ \\
\hline Unrated & 0.16 & $(0.10)$ \\
\hline Log Total Assets & $-0.06^{* *}$ & $(0.03)$ \\
\hline Log Age & -0.07 & $(0.05)$ \\
\hline EBIT/Total Assets & -0.26 & $(0.20)$ \\
\hline Market-to-Book & -0.02 & $(0.04)$ \\
\hline Public Debt Issuance & $-0.35^{* * *}$ & $(0.12)$ \\
\hline Past Non-Bank Loans & $1.79^{* * *}$ & $(0.14)$ \\
\hline Log Number Prior Loans & $-0.17^{* * *}$ & $(0.04)$ \\
\hline Cross-Selling Opportunity & $-0.15^{* *}$ & $(0.06)$ \\
\hline \multicolumn{3}{|l|}{ Loan Variables } \\
\hline Log Maturity & 0.03 & $(0.06)$ \\
\hline Secured & $0.20^{* *}$ & $(0.09)$ \\
\hline Sponsored & 0.18 & $(0.12)$ \\
\hline End of Quarter Loan & 0.11 & $(0.07)$ \\
\hline Refinancing & $-0.19^{* * *}$ & $(0.07)$ \\
\hline Other Control Variables \& Fixed Effects & \multicolumn{2}{|c|}{ Yes } \\
\hline Observations & \multicolumn{2}{|c|}{9,500} \\
\hline Pseudo R-squared & \multicolumn{2}{|c|}{0.18} \\
\hline
\end{tabular}




\section{Table 10}

System Estimation: Choice of Lead Arranger, Syndication vs Sole-Lender Loan and Concrete Participants - Robustness Test This table presents an SUR model which estimates the equations from Table $4-6$ as a system controlling for potentially correlated errors across equations. Definitions of all variables can be found in Table 1. Other control variables contain the variables Total HHI, Tightening Standards, Number Main Offices and Local HHI. Fixed effects contain time, industry, loan purpose and loan type fixed effects. Standard errors are clustered by borrower. ${ }^{* *},{ }^{* *}$, and ${ }^{*}$ correspond to the statistical significance levels of $1 \%, 5 \%$ and $10 \%$, respectively.

\begin{tabular}{|c|c|c|}
\hline \multirow[b]{2}{*}{ Variables } & \multicolumn{2}{|c|}{$\begin{array}{c}\text { Non-Bank Lead Arranger vs } \\
\text { Bank Lead Arranger (1) }\end{array}$} \\
\hline & Coef. & Se. \\
\hline \multicolumn{3}{|l|}{ Borrower Variables } \\
\hline Z-Score & -0.03 & $(0.03)$ \\
\hline Leverage & -0.03 & $(0.11)$ \\
\hline Unrated & 0.09 & $(0.08)$ \\
\hline Log Total Assets & $-0.09^{* * *}$ & $(0.02)$ \\
\hline Log Age & -0.02 & $(0.04)$ \\
\hline EBIT/Total Assets & -0.26 & $(0.20)$ \\
\hline Market-to-Book & 0.00 & $(0.03)$ \\
\hline Public Debt Issuance & $-0.37^{* * *}$ & $(0.10)$ \\
\hline Past Non-Bank Loans & $1.71^{* * *}$ & $(0.12)$ \\
\hline Log Number Prior Loans & $-0.16^{* * *}$ & $(0.04)$ \\
\hline Cross-Selling Opportunity & $-0.13^{* *}$ & $(0.05)$ \\
\hline \multicolumn{3}{|l|}{ Loan Variables } \\
\hline Log Maturity & 0.04 & $(0.05)$ \\
\hline Secured & $0.16^{* *}$ & $(0.08)$ \\
\hline Sponsored & 0.08 & $(0.10)$ \\
\hline End of Quarter Loan & 0.10 & $(0.06)$ \\
\hline Refinancing & $-0.15^{* *}$ & $(0.06)$ \\
\hline Other Control Variables \& Fixed Effects & \multicolumn{2}{|c|}{ Yes } \\
\hline & \multicolumn{2}{|c|}{ Syndication (2) } \\
\hline Variables & Coef. & Se. \\
\hline \multicolumn{3}{|l|}{ Base Effect - Bank Lead Arrangers } \\
\hline \multicolumn{3}{|l|}{ Borrower Variables } \\
\hline Z-Score & 0.00 & $(0.02)$ \\
\hline Leverage & $0.21^{*}$ & $(0.11)$ \\
\hline Unrated & 0.03 & $(0.06)$ \\
\hline Log Total Assets & $0.42^{* * *}$ & $(0.03)$ \\
\hline Log Age & 0.02 & $(0.02)$ \\
\hline EBIT/Total Assets & $1.26^{* * *}$ & $(0.23)$ \\
\hline Market-to-Book & 0.00 & $(0.02)$ \\
\hline Public Debt Issuance & $0.22^{* * *}$ & $(0.07)$ \\
\hline Past Non-Bank Loans & 0.03 & $(0.16)$ \\
\hline
\end{tabular}

(continued) 
Table 10 - continued

\begin{tabular}{|c|c|c|}
\hline Log Number Prior Loans & $0.10^{* * *}$ & $(0.03)$ \\
\hline Cross-Selling Opportunity & $0.09^{* *}$ & $(0.04)$ \\
\hline \multicolumn{3}{|l|}{ Loan Variables } \\
\hline Log Maturity & $0.42^{* * *}$ & $(0.04)$ \\
\hline Secured & -0.08 & $(0.06)$ \\
\hline Sponsored & $0.44^{* * *}$ & $(0.10)$ \\
\hline End of Quarter Loan & 0.01 & $(0.05)$ \\
\hline Refinancing & $0.35^{* * *}$ & $(0.05)$ \\
\hline Lead Arranger Former Lead & $0.15^{* * *}$ & $(0.05)$ \\
\hline Lead Arranger Market Share & $0.02^{* * *}$ & $(0.00)$ \\
\hline Log Distance Lead Arrangers vs Borrower & -0.01 & $(0.01)$ \\
\hline \multicolumn{3}{|l|}{-} \\
\hline Non-Bank-Led & 1.63 & $(1.16)$ \\
\hline \multicolumn{3}{|l|}{ - } \\
\hline \multicolumn{3}{|l|}{ Interacted Borrower Variables } \\
\hline Interacted Z-Score & 0.00 & $(0.05)$ \\
\hline Interacted Leverage & -0.01 & $(0.36)$ \\
\hline Interacted Unrated & 0.03 & $(0.22)$ \\
\hline Interacted Log Total Assets & $-0.19^{* *}$ & $(0.08)$ \\
\hline Interacted Log Age & 0.04 & $(0.09)$ \\
\hline Interacted EBIT/Total Assets & $-2.01^{* * *}$ & $(0.74)$ \\
\hline Interacted Market-to-Book & -0.02 & $(0.07)$ \\
\hline Interacted Public Debt Issuance & $-0.65^{* *}$ & $(0.33)$ \\
\hline Interacted Past Non-Bank Loans & 0.13 & $(0.34)$ \\
\hline Interacted Log Number Prior Loans & 0.03 & $(0.10)$ \\
\hline Interacted Cross-Selling Opportunity & 0.03 & $(0.15)$ \\
\hline \multicolumn{3}{|l|}{ Interacted Loan Variables } \\
\hline Interacted Log Maturity & -0.01 & $(0.15)$ \\
\hline Interacted Secured & -0.23 & $(0.26)$ \\
\hline Interacted Sponsored & 0.41 & $(0.29)$ \\
\hline Interacted End of Quarter Loan & 0.12 & $(0.16)$ \\
\hline Interacted Refinancing & $-0.51^{* * *}$ & $(0.17)$ \\
\hline Interacted Lead Arranger Former Lead & -0.02 & $(0.30)$ \\
\hline Interacted Lead Arranger Market Share & 0.00 & $(0.05)$ \\
\hline Interacted Log Distance Lead Arrangers vs Borrower & -0.01 & $(0.05)$ \\
\hline Other Control Variables \& Fixed Effects & \multicolumn{2}{|c|}{ Yes } \\
\hline
\end{tabular}

(continued) 


\section{Potential Participant (3)}

Variables

Coef.

Se.

Base Effect - Bank Lead Arrangers

Potential Participant Former Lead

$-0.04 \quad(0.03)$

Potential Participant Former Participant

$0.67^{* * *}$

Potential Participant Non-Bank

$0.12^{* * *}$

Log Distance Potential Participant vs Borrower

$-0.05^{* * *}$

Was Participant with Current Lead Last 3 Years

$0.12^{* * *}$

Log Distance Lead Arranger vs Potential Participant

$0.01^{* * *}$

\section{Specific Intercept}

Non-Bank-Led

Interaction Effect - Non-Bank Lead Arrangers

Interacted Potential Participant Former Lead

$0.23^{*}$

Interacted Potential Participant Former Participant

$-0.13^{*}$

Interacted Potential Participant Non-Bank

$0.30^{* *}$

Interacted Log Distance Potential Participant vs Borrower

$-0.04^{* *}$

Interacted Was Participant with Current Lead Last 3 Years

$0.22^{* * *}$

Interacted Log Distance Lead Arranger vs Potential Participant

0.02

\section{Borrower Variables}

Yes

Loan Variables

Yes

Other Control Variables \& Fixed Effects

Yes

Correlation Errors Equations (1) and (2)

0.01

$-0.16$

(0.00)

Correlation Errors Equations (1) and (3)

$-0.14$

Correlation Errors Equations (2) and (3)

$(0.10)$ 


\section{Table 11}

Quality of Syndication Process - Robustness Test

Panel A presents the coefficient estimates of a probit regression with the flexed loan dummy as dependent variable which indicates whether the loan pricing had been adjusted during the syndication process. Panel B presents the coefficient estimates of an OLS regression with the time-on-the-market as dependent variables indicating the length of the syndication process. Definitions of all variables can be found in Table 1. Other control variables contain the variables Total HHI, Tightening Standards, Number Main Offices and Local HHI. Fixed effects contain time, industry, loan purpose and loan type fixed effects. Standard errors are clustered by borrower. ${ }^{* *}, * *$, and ${ }^{*}$ correspond to the statistical significance levels of $1 \%, 5 \%$ and $10 \%$, respectively.

Panel A: Re-adjustment of loan pricing in syndication process

\begin{tabular}{|c|c|c|}
\hline \multirow[b]{2}{*}{ Variables } & \multicolumn{2}{|c|}{ Flexed Dummy } \\
\hline & Coef. & Se. \\
\hline \multicolumn{3}{|l|}{ Specific Intercept } \\
\hline Non-Bank-Led & $-0.83^{* * *}$ & $(0.23)$ \\
\hline \multicolumn{3}{|l|}{ Borrower Variables } \\
\hline Z-Score & 0.00 & $(0.05)$ \\
\hline Leverage & -0.12 & $(0.18)$ \\
\hline Unrated & -0.06 & $(0.14)$ \\
\hline Log Total Assets & 0.04 & $(0.06)$ \\
\hline Log Age & 0.01 & $(0.05)$ \\
\hline EBIT/Total Assets & -0.16 & $(0.23)$ \\
\hline Market-to-Book & 0.03 & $(0.06)$ \\
\hline Public Debt Issuance & -0.01 & $(0.11)$ \\
\hline Past Non-Bank Loans & 0.36 & $(0.24)$ \\
\hline Log Number Prior Loans & -0.06 & $(0.06)$ \\
\hline Cross-Selling Opportunity & 0.10 & $(0.10)$ \\
\hline \multicolumn{3}{|l|}{ Loan Variables } \\
\hline Log Facility Amount & $0.15^{* * *}$ & $(0.05)$ \\
\hline Log Syndicate Size & $0.21^{* * *}$ & $(0.06)$ \\
\hline Log Maturity & $0.48^{* * *}$ & $(0.17)$ \\
\hline Secured & $0.34^{* *}$ & $(0.14)$ \\
\hline Sponsored & 0.19 & $(0.12)$ \\
\hline End of Quarter Loan & 0.00 & $(0.10)$ \\
\hline Refinancing & 0.09 & $(0.12)$ \\
\hline Lead Arranger Former Lead & 0.06 & $(0.12)$ \\
\hline Lead Arranger Market Share & $-0.02^{*}$ & $(0.01)$ \\
\hline Log Distance Lead Arrangers vs Borrower & 0.02 & $(0.04)$ \\
\hline Contract Intensity Index & -0.04 & $(0.03)$ \\
\hline Performance Pricing & -0.03 & $(0.10)$ \\
\hline Relationship Score & -0.19 & $(0.86)$ \\
\hline Other Control Variables \& Fixed Effects & \multicolumn{2}{|c|}{ Yes } \\
\hline Observations & \multicolumn{2}{|c|}{10,326} \\
\hline Adjusted R-squared & \multicolumn{2}{|c|}{0.25} \\
\hline
\end{tabular}


Panel B: Time-on-the-market

\begin{tabular}{|c|c|c|}
\hline \multirow[b]{2}{*}{ Variables } & \multicolumn{2}{|c|}{ Time-on-the-Market } \\
\hline & Coef. & Se. \\
\hline \multicolumn{3}{|l|}{ Specific Intercept } \\
\hline Non-Bank-Led & -16.29 & $(10.22)$ \\
\hline \multicolumn{3}{|l|}{ Borrower Variables } \\
\hline Z-Score & 0.49 & $(1.31)$ \\
\hline Leverage & -1.37 & $(4.02)$ \\
\hline Unrated & -2.21 & (2.43) \\
\hline Log Total Assets & -1.39 & $(1.02)$ \\
\hline Log Age & 0.14 & $(0.99)$ \\
\hline EBIT/Total Assets & -9.79 & $(18.18)$ \\
\hline Market-to-Book & 1.78 & $(1.10)$ \\
\hline Public Debt Issuance & -2.02 & $(2.55)$ \\
\hline Past Non-Bank Loans & $-9.81^{* *}$ & $(3.80)$ \\
\hline Log Number Prior Loans & 0.61 & $(1.01)$ \\
\hline Cross-Selling Opportunity & 1.10 & $(2.06)$ \\
\hline \multicolumn{3}{|l|}{ Loan Variables } \\
\hline Log Facility Amount & 0.9 & $(1.04)$ \\
\hline Log Syndicate Size & $3.64^{* *}$ & (1.76) \\
\hline Log Maturity & $4.07^{* *}$ & $(2.00)$ \\
\hline Secured & 2.77 & $(3.21)$ \\
\hline Sponsored & -0.03 & (2.67) \\
\hline End of Quarter Loan & -0.86 & (2.12) \\
\hline Refinancing & 0.02 & (2.58) \\
\hline Lead Arranger Former Lead & $-4.16^{* *}$ & $(2.05)$ \\
\hline Lead Arranger Market Share & $-0.78^{* *}$ & $(0.34)$ \\
\hline Log Distance Lead Arrangers vs Borrower & 0.76 & $(0.72)$ \\
\hline Contract Intensity Index & 0.18 & $(0.60)$ \\
\hline Performance Pricing & 3.24 & $(2.16)$ \\
\hline Relationship Score & -8.68 & $(20.49)$ \\
\hline Other Control Variables \& Fixed Effects & \multicolumn{2}{|c|}{ Yes } \\
\hline Observations & \multicolumn{2}{|c|}{1,766} \\
\hline Adjusted R-squared & \multicolumn{2}{|c|}{0.05} \\
\hline
\end{tabular}




\section{Table 12}

Substitutes: Public Debt Issuance vs. Syndicated Loans - Robustness Test

This table presents a probit testing influence of syndicate structures on future public debt issuance. Definitions of all variables can be found in Table 1. Other control variables contain Total HHI, Tightening Standards, Number Main Offices and Local HHI. Fixed effects contain time, industry, loan purpose and loan type fixed effects. Standard errors are clustered by borrower. ${ }^{* *},{ }^{* *}$, and ${ }^{*}$ correspond to the statistical significance levels of $1 \%, 5 \%$ and $10 \%$, respectively.

\begin{tabular}{|c|c|c|}
\hline \multirow[b]{2}{*}{ Variables } & \multicolumn{2}{|c|}{ Public Debt Issuance Next 3 Years } \\
\hline & Coef. & Se. \\
\hline \multicolumn{3}{|l|}{ Specific Intercepts } \\
\hline Bank-Led With Non-Bank Participants & 0.03 & $(0.05)$ \\
\hline Non-Bank-Led & $-0.25^{* *}$ & $(0.12)$ \\
\hline \multicolumn{3}{|l|}{ Borrower Variables } \\
\hline Z-Score & 0.00 & $(0.02)$ \\
\hline Leverage & $0.26^{* *}$ & $(0.11)$ \\
\hline Unrated & $-0.38^{* * *}$ & $(0.06)$ \\
\hline Log Total Assets & $0.19^{* * *}$ & $(0.03)$ \\
\hline Log Age & -0.01 & $(0.03)$ \\
\hline EBIT/Total Assets & $0.59^{* *}$ & $(0.28)$ \\
\hline Market-to-Book & $-0.05^{*}$ & $(0.03)$ \\
\hline Past Non-Bank Loans & $0.23^{*}$ & $(0.13)$ \\
\hline Log Number Prior Loans & 0.05 & $(0.03)$ \\
\hline Cross-Selling Opportunity & $0.50^{* * *}$ & $(0.04)$ \\
\hline \multicolumn{3}{|l|}{ Loan Variables } \\
\hline Log Facility Amount & $0.05^{* *}$ & $(0.02)$ \\
\hline Log Syndicate Size & $0.08^{* *}$ & $(0.03)$ \\
\hline Log Maturity & $0.24^{* * *}$ & $(0.04)$ \\
\hline Secured & -0.07 & $(0.06)$ \\
\hline Sponsored & 0.03 & $(0.07)$ \\
\hline End of Quarter Loan & -0.04 & $(0.04)$ \\
\hline Refinancing & $-0.13^{* * *}$ & $(0.05)$ \\
\hline Lead Arranger Former Lead & -0.04 & $(0.05)$ \\
\hline Lead Arranger Market Share & 0.00 & $(0.00)$ \\
\hline Log Distance Lead Arrangers vs Borrower & 0.01 & $(0.01)$ \\
\hline Contract Intensity Index & $0.05^{* * *}$ & $(0.01)$ \\
\hline Performance Pricing & 0.00 & $(0.04)$ \\
\hline Relationship Score & 0.08 & $(0.38)$ \\
\hline Other Control Variables E Fixed Effects & \multicolumn{2}{|c|}{ Yes } \\
\hline Observations & \multicolumn{2}{|c|}{12,847} \\
\hline Adjusted R-squared & \multicolumn{2}{|c|}{0.21} \\
\hline
\end{tabular}




\section{Table 13}

Choice of Non-Bank Participants vs. Bank-Only Loans - Robustness Test

This table presents the probit regression coefficient estimates of the determinants of the choice of non-bank participants by bank lead arrangers compared to bank-arranged loans. The dependent variable is 1 for loans with at least one non-bank lender and 0 for bank-only loans. Other control variables contain the variables Total HHI, Tightening Standards, Number Main Offices and Local HHI. Fixed effects contain time, industry, loan purpose and loan type fixed effects. Standard errors are clustered by borrower. ${ }^{* * *},{ }^{* *}$, and ${ }^{*}$ correspond to the statistical significance levels of $1 \%, 5 \%$ and $10 \%$, respectively.

\begin{tabular}{|c|c|c|}
\hline \multirow[b]{2}{*}{ Variables } & \multicolumn{2}{|c|}{ At Least One Non-Bank vs Bank-Only } \\
\hline & Coef. & Se. \\
\hline \multicolumn{3}{|l|}{ Borrower Variables } \\
\hline Z-Score & $0.04^{*}$ & $(0.02)$ \\
\hline Leverage & $0.28^{* * *}$ & $(0.10)$ \\
\hline Unrated & $-0.19^{* * *}$ & $(0.06)$ \\
\hline Log Total Assets & 0.02 & $(0.02)$ \\
\hline Log Age & -0.04 & $(0.02)$ \\
\hline EBIT/Total Assets & $-1.48^{* * *}$ & $(0.32)$ \\
\hline Market-to-Book & -0.02 & $(0.03)$ \\
\hline Public Debt Issuance & $0.10^{* *}$ & $(0.05)$ \\
\hline Past Non-Bank Loans & $0.34^{* *}$ & $(0.17)$ \\
\hline Log Number Prior Loans & $0.06^{* *}$ & $(0.03)$ \\
\hline Cross-Selling Opportunity & -0.03 & $(0.04)$ \\
\hline \multicolumn{3}{|l|}{ Loan Variables } \\
\hline Log Maturity & $0.18^{* * *}$ & $(0.05)$ \\
\hline Secured & $0.39^{* * *}$ & $(0.05)$ \\
\hline Sponsored & $0.21^{* * *}$ & $(0.06)$ \\
\hline End of Quarter Loan & 0.00 & $(0.05)$ \\
\hline Refinancing & 0.03 & $(0.05)$ \\
\hline Lead Arranger Former Lead & 0.05 & $(0.05)$ \\
\hline Lead Arranger Market Share & -0.01 & $(0.00)$ \\
\hline Log Distance Lead Arrangers vs Borrower & $0.04^{* * *}$ & $(0.02)$ \\
\hline Other Control Variables E Fixed Effects & \multicolumn{2}{|c|}{ Yes } \\
\hline Observations & \multicolumn{2}{|c|}{9,539} \\
\hline Pseudo R-squared & \multicolumn{2}{|c|}{0.10} \\
\hline
\end{tabular}




\section{Table 14}

Differences in Loan Pricing - Robustness Test (1/2)

This table presents an OLS regression testing the pricing differences among bank-only (base case), bank-led with non-bank participants and non-bank-led loans. Definitions of all variables can be found in Table 1. The estimates are conditional on the choice of banks as lead arrangers and having a syndicated loan. The dependent variable is 1 for loans with at least one non-bank lender and 0 for bank-only loans. Other control variables contain the variables Total HHI, Tightening Standards, Number Main Offices and Local HHI. Fixed effects contain time, industry, loan purpose and loan type fixed effects. Standard errors are clustered by borrower. ${ }^{* *},{ }^{* *}$, and ${ }^{*}$ correspond to the statistical significance levels of $1 \%, 5 \%$ and $10 \%$, respectively.

\begin{tabular}{|c|c|c|}
\hline \multirow[b]{2}{*}{ Variables } & \multicolumn{2}{|c|}{ AISD } \\
\hline & Coef. & Se. \\
\hline \multicolumn{3}{|l|}{ Specific Intercept } \\
\hline Bank-Led With Non-Bank Participants & $23.78^{* * *}$ & $(3.00)$ \\
\hline Non-Bank-Led & $109.77^{* * *}$ & $(12.21)$ \\
\hline \multicolumn{3}{|l|}{ Borrower Variables } \\
\hline Z-Score & $-7.96^{* * *}$ & $(1.23)$ \\
\hline Leverage & 7.85 & $(6.12)$ \\
\hline Unrated & -1.50 & $(3.71)$ \\
\hline Log Total Assets & $2.22^{*}$ & $(1.31)$ \\
\hline Log Age & $-2.33^{*}$ & $(1.29)$ \\
\hline EBIT/Total Assets & $-51.57^{* * *}$ & $(18.10)$ \\
\hline Market-to-Book & 0.81 & $(1.47)$ \\
\hline Public Debt Issuance & -0.28 & $(3.49)$ \\
\hline Past Non-Bank Loans & $21.18^{* *}$ & $(9.66)$ \\
\hline Log Number Prior Loans & 1.33 & $(1.70)$ \\
\hline Cross-Selling Opportunity & -1.31 & $(2.27)$ \\
\hline \multicolumn{3}{|l|}{ Loan Variables } \\
\hline Log Facility Amount & $-6.68^{* * *}$ & $(1.15)$ \\
\hline Log Syndicate Size & $-22.60^{* * *}$ & $(2.39)$ \\
\hline Log Maturity & $-12.74^{* * *}$ & $(2.73)$ \\
\hline Secured & $13.43^{* * *}$ & $(3.77)$ \\
\hline Sponsored & $10.60^{* * *}$ & $(3.56)$ \\
\hline End of Quarter Loan & -0.93 & $(2.50)$ \\
\hline Refinancing & $-10.71^{* * *}$ & $(2.86)$ \\
\hline Lead Arranger Former Lead & $-7.22^{* * *}$ & $(2.60)$ \\
\hline Lead Arranger Market Share & $-0.50^{* *}$ & $(0.22)$ \\
\hline Log Distance Lead Arrangers vs Borrower & 0.79 & $(0.72)$ \\
\hline Contract Intensity Index & $8.19^{* * *}$ & $(0.96)$ \\
\hline Performance Pricing & $-38.90^{* * *}$ & $(2.43)$ \\
\hline Relationship Score & $-71.44^{* * *}$ & $(23.00)$ \\
\hline Syndication & $31.66^{* * *}$ & $(4.51)$ \\
\hline Other Control Variables E Fixed Effects & \multicolumn{2}{|c|}{ Yes } \\
\hline Observations & \multicolumn{2}{|c|}{12,847} \\
\hline Adjusted R-squared & \multicolumn{2}{|c|}{0.33} \\
\hline
\end{tabular}




\section{Table 15}

Differences in Loan Pricing - Robustness Test (2/2)

This table presents an OLS regression testing the pricing differences among bank-arranged and non-bank-led loans. Definitions of all variables can be found in Table 1. Other control variables contain the variables Total HHI, Tightening Standards, Number Main Offices and Local HHI. Fixed effects contain time, industry, loan purpose and loan type fixed effects. Standard errors are clustered by borrower. ${ }^{* *},{ }^{* *}$, and ${ }^{*}$ correspond to the statistical significance levels of $1 \%, 5 \%$ and $10 \%$, respectively.

\begin{tabular}{|c|c|c|c|c|c|c|}
\hline \multirow[b]{2}{*}{ Variables } & \multicolumn{2}{|c|}{$\begin{array}{c}\text { Exclusion of GE } \\
\text { Capital Corp } \\
\text { AISD }\end{array}$} & \multicolumn{2}{|c|}{$\begin{array}{c}\text { Lead Arranger Credit } \\
\text { Rating Fixed Effects } \\
\text { AISD }\end{array}$} & \multicolumn{2}{|c|}{$\begin{array}{c}\text { Lead Arranger } \\
\text { Fixed Effects } \\
\text { AISD }\end{array}$} \\
\hline & Coef. & Se. & Coef. & Se. & Coef. & Se. \\
\hline \multicolumn{7}{|l|}{ Specific Intercepts } \\
\hline Non-Bank-Led & $114.56^{* * *}$ & (13.18) & $96.16^{* * *}$ & $(10.96)$ & $114.81^{*}$ & $(61.25)$ \\
\hline \multicolumn{7}{|l|}{ Borrower Variables } \\
\hline Z-Score & $-7.41^{* * *}$ & $(1.25)$ & $-7.73^{* * *}$ & $(1.27)$ & $-6.61^{* * *}$ & $(1.14)$ \\
\hline Leverage & $10.86^{*}$ & $(6.15)$ & 9.92 & $(6.11)$ & $13.62^{* *}$ & $(5.77)$ \\
\hline Unrated & -3.72 & $(3.79)$ & -2.88 & $(3.73)$ & -2.03 & $(3.69)$ \\
\hline Log Total Assets & 1.60 & $(1.33)$ & 1.74 & $(1.33)$ & 0.80 & $(1.36)$ \\
\hline Log Age & $-3.03^{* *}$ & $(1.32)$ & $-2.50^{*}$ & $(1.30)$ & $-2.44^{*}$ & $(1.27)$ \\
\hline EBIT/Total Assets & $-54.18^{* * *}$ & $(18.31)$ & $-53.47^{* * *}$ & $(19.44)$ & $-73.34^{* * *}$ & $(16.58)$ \\
\hline Market-to-Book & -0.50 & $(1.45)$ & 0.21 & $(1.48)$ & -0.08 & $(1.40)$ \\
\hline Public Debt Issuance & 0.63 & $(3.56)$ & 0.21 & $(3.53)$ & -2.11 & $(3.41)$ \\
\hline Past Non-Bank Loans & 17.71 & $(11.62)$ & $23.83^{* *}$ & $(9.55)$ & $23.17^{* *}$ & $(9.32)$ \\
\hline Log Number Prior Loans & 1.36 & $(1.75)$ & 1.32 & $(1.71)$ & -0.05 & $(1.64)$ \\
\hline Cross-Selling Opportunity & -1.24 & $(2.29)$ & -1.60 & $(2.27)$ & -1.95 & $(2.22)$ \\
\hline \multicolumn{7}{|l|}{ Loan Variables } \\
\hline Log Facility Amount & $-5.98^{* * *}$ & $(1.16)$ & $-6.50^{* * *}$ & $(1.17)$ & $-7.73^{* * *}$ & (1.15) \\
\hline Log Syndicate Size & $-18.91^{* * *}$ & $(2.36)$ & $-18.35^{* * *}$ & $(2.35)$ & $-15.80^{* * *}$ & $(2.29)$ \\
\hline Log Maturity & $-11.38^{* * *}$ & $(2.77)$ & $-12.48^{* * *}$ & $(2.77)$ & $-12.70^{* * *}$ & $(2.75)$ \\
\hline Secured & $13.95^{* * *}$ & $(3.76)$ & $15.60^{* * *}$ & $(3.78)$ & $17.66^{* * *}$ & $(3.76)$ \\
\hline Sponsored & $10.68^{* * *}$ & $(3.56)$ & $11.41^{* * *}$ & $(3.57)$ & $9.78^{* * *}$ & $(3.70)$ \\
\hline End of Quarter Loan & -1.54 & $(2.54)$ & -1.07 & $(2.51)$ & -1.66 & $(2.43)$ \\
\hline Refinancing & $-9.97^{* * *}$ & $(2.88)$ & $-11.14^{* * *}$ & $(2.87)$ & $-10.49^{* * *}$ & $(2.79)$ \\
\hline Lead Arranger Former Lead & $-6.63^{* *}$ & $(2.66)$ & $-6.90^{* * *}$ & $(2.61)$ & -2.53 & $(2.58)$ \\
\hline Lead Arranger Market Share & $-0.61^{* * *}$ & $(0.23)$ & $-0.45^{*}$ & $(0.25)$ & -0.60 & $(0.51)$ \\
\hline $\begin{array}{l}\text { Log Distance Lead Arrangers vs } \\
\text { Borrower }\end{array}$ & 1.19 & $(0.73)$ & 0.99 & $(0.73)$ & 0.66 & $(0.70)$ \\
\hline Contract Intensity Index & $8.95^{* * *}$ & $(0.97)$ & $8.25^{* * *}$ & $(0.97)$ & $6.47^{* * *}$ & $(0.93)$ \\
\hline Performance Pricing & $-40.01^{* * *}$ & $(2.49)$ & $-39.62^{* * *}$ & $(2.46)$ & $-36.34^{* * *}$ & $(2.34)$ \\
\hline Relationship Score & $-69.04^{* * *}$ & $(23.26)$ & $-75.06^{* * *}$ & $(23.57)$ & $-101.91^{* * *}$ & $(24.55)$ \\
\hline Syndication & $31.17^{* * *}$ & $(4.53)$ & $33.73^{* * *}$ & $(4.58)$ & $32.92^{* * *}$ & $(4.50)$ \\
\hline Other Control Variables E Fixed Effects & \multicolumn{2}{|c|}{ Yes } & \multicolumn{2}{|c|}{ Yes } & \multicolumn{2}{|c|}{ Yes } \\
\hline Observations & \multicolumn{2}{|c|}{12,419} & \multicolumn{2}{|c|}{12,847} & \multicolumn{2}{|c|}{12,847} \\
\hline Adjusted R-squared & \multicolumn{2}{|c|}{0.32} & \multicolumn{2}{|c|}{0.33} & \multicolumn{2}{|c|}{0.38} \\
\hline
\end{tabular}




\section{Table 16}

Drivers of Differences in Loan Pricing - Robustness Test (1/2)

This table presents OLS regressions testing the drivers of pricing differences between non-bank-arranged loans and bankled by adding interactions of variables discussed in section 5.3 with the non-bank-led dummy. Columns (2) and (3) present the model with excluding General Electric Capital Corp as lead arranger as this company is the largest non-bank lender. Columns (4) and (5) show the results with lead arranger credit rating fixed effects. Columns (6) and (7) are estimated with lead arranger fixed effects. Definitions of all variables can be found in Table 1. Other control variables contain the variables Total HHI, Tightening Standards, Number Main Offices and Local HHI. Fixed effects contain time, industry, loan purpose and loan type fixed effects. Standard errors are clustered by borrower. ${ }^{* *},{ }^{* *}$, and ${ }^{*}$ correspond to the statistical significance levels of $1 \%, 5 \%$ and $10 \%$, respectively.

\begin{tabular}{|c|c|c|c|c|c|c|}
\hline \multirow[b]{2}{*}{ Variables } & \multicolumn{2}{|c|}{$\begin{array}{l}\text { Exclusion of GE } \\
\text { Capital Corp } \\
\text { AISD }\end{array}$} & \multicolumn{2}{|c|}{$\begin{array}{c}\text { Lead Arranger Credit Rating } \\
\text { Fixed Effects } \\
\text { AISD }\end{array}$} & \multicolumn{2}{|c|}{$\begin{array}{c}\text { Lead Arranger Fixed } \\
\text { Effects } \\
\text { AISD }\end{array}$} \\
\hline & Coef. & Se. & Coef. & Se. & Coef. & Se. \\
\hline \multicolumn{7}{|l|}{ Specific Intercepts } \\
\hline $\begin{array}{l}\text { Non-Bank-Led } \\
\text { Interactions with Non-Bank- } \\
\text { Led Dummy } \\
\text { Interacted Cross-Selling }\end{array}$ & $322.79^{* *}$ & $(131.78)$ & $271.46^{* * *}$ & $(78.68)$ & 174.12 & $(106.51)$ \\
\hline Opportunity & 11.49 & $(22.19)$ & 6.08 & $(13.10)$ & 5.59 & $(12.62)$ \\
\hline Interacted Unrated & $50.09^{*}$ & $(27.24)$ & $36.27^{* *}$ & $(14.63)$ & $33.51^{* *}$ & $(14.00)$ \\
\hline Interacted Total Assets & 14.53 & $(12.08)$ & 8.88 & $(6.16)$ & 8.17 & $(6.49)$ \\
\hline Interacted Market-to-Book & $23.82^{* *}$ & $(11.71)$ & $17.52^{* *}$ & $(7.51)$ & $16.04^{* *}$ & $(6.80)$ \\
\hline Interacted Z-Score & -1.98 & $(7.42)$ & -4.79 & $(5.30)$ & -0.03 & $(4.66)$ \\
\hline Interacted Leverage & $\begin{array}{c}-67.72 \\
-\end{array}$ & $(47.39)$ & $-53.12^{*}$ & $(27.17)$ & -16 & $(24.46)$ \\
\hline $\begin{array}{l}\text { Interacted Relationship Score } \\
\text { Interacted Lead Arranger }\end{array}$ & $762.08^{* * *}$ & $(183.56)$ & $-312.96^{* * *}$ & $(108.15)$ & $-190.71^{*}$ & $(101.69)$ \\
\hline Market Share & $-66.88^{* * *}$ & $(16.28)$ & $-23.61^{* * *}$ & $(7.60)$ & -8.08 & $(10.47)$ \\
\hline Interacted Performance Pricing & $-32.97^{*}$ & $(18.54)$ & $-34.65^{* * *}$ & $(10.81)$ & $-22.91^{* *}$ & $(10.28)$ \\
\hline $\begin{array}{l}\text { Interacted Total HHI } \\
\text { Interacted Tightening }\end{array}$ & $-0.58^{* * *}$ & $(0.19)$ & $-0.42^{* * *}$ & $(0.12)$ & $-0.26^{* *}$ & $(0.13)$ \\
\hline Standards & -0.29 & $(0.61)$ & $-0.67^{* *}$ & $(0.31)$ & $-0.52^{*}$ & $(0.29)$ \\
\hline Borrower Variables & & & & & & \\
\hline Z-Score & $-7.07^{* * *}$ & $(1.20)$ & $-6.94^{* * *}$ & $(1.20)$ & $-6.56^{* * *}$ & $(1.17)$ \\
\hline Leverage & $13.56^{* *}$ & $(6.02)$ & $13.91^{* *}$ & $(6.01)$ & $14.68^{* *}$ & $(5.88)$ \\
\hline Unrated & -5.2 & $(3.82)$ & -5.3 & $(3.82)$ & -4.02 & $(3.80)$ \\
\hline Log Total Assets & 1.17 & $(1.34)$ & 1.1 & $(1.33)$ & 0.35 & $(1.36)$ \\
\hline Log Age & $-2.88^{* *}$ & $(1.31)$ & $-2.39^{*}$ & $(1.28)$ & $-2.38^{*}$ & $(1.26)$ \\
\hline EBIT/Total Assets & $-55.82^{* * *}$ & $(17.53)$ & $-56.56^{* * *}$ & $(17.93)$ & $-72.68^{* * *}$ & $(16.50)$ \\
\hline Market-to-Book & -2.04 & $(1.37)$ & $-2.27^{*}$ & $(1.37)$ & -1.57 & $(1.32)$ \\
\hline Public Debt Issuance & 0.38 & $(3.55)$ & -0.12 & $(3.52)$ & -2.4 & $(3.41)$ \\
\hline Past Non-Bank Loans & $19.01^{*}$ & $(11.55)$ & $21.78^{* *}$ & $(9.50)$ & $20.64^{* *}$ & $(9.46)$ \\
\hline Log Number Prior Loans & 1.11 & $(1.74)$ & 1.09 & $(1.68)$ & -0.13 & $(1.63)$ \\
\hline Cross-Selling Opportunity & -1.71 & $(2.27)$ & -1.78 & $(2.26)$ & -2.12 & $(2.23)$ \\
\hline
\end{tabular}


Table 16 - continued

\begin{tabular}{|c|c|c|c|c|c|c|}
\hline \multicolumn{7}{|l|}{ Loan Variables } \\
\hline Log Facility Amount & $-5.42^{* * *}$ & $(1.17)$ & $-6.09^{* * *}$ & $(1.17)$ & $-7.53^{* * *}$ & $(1.15)$ \\
\hline \multirow{2}{*}{$\begin{array}{l}\text { Log Syndicate Size } \\
\text { Log Maturity }\end{array}$} & $-19.13^{* * *}$ & (2.35) & $-18.54^{* * *}$ & $(2.33)$ & $-15.96^{* * *}$ & $(2.28)$ \\
\hline & $-12.07^{* * *}$ & $(2.76)$ & $-12.91^{* * *}$ & $(2.75)$ & $-12.65^{* * *}$ & $(2.74)$ \\
\hline Secured & $14.30^{* * *}$ & $(3.70)$ & $15.35^{* * *}$ & $(3.72)$ & $17.28^{* * *}$ & $(3.75)$ \\
\hline $\begin{array}{l}\text { Sponsored } \\
\text { End of Quarter Loan }\end{array}$ & $9.61^{* * *}$ & $(3.61)$ & $10.23^{* * *}$ & $(3.61)$ & $8.82^{* *}$ & $(3.71)$ \\
\hline End of Quarter Loan & -1.14 & $(2.51)$ & -0.72 & $(2.50)$ & -1.57 & (2.41) \\
\hline Refinancing & $-9.08^{* * *}$ & $(2.84)$ & $-10.64^{* * *}$ & $(2.85)$ & $-10.42^{* * *}$ & $(2.79)$ \\
\hline Lead Arranger Former Lead & $-6.20^{* *}$ & $(2.64)$ & $-6.16^{* *}$ & $(2.60)$ & -2.38 & $(2.58)$ \\
\hline Lead Arranger Market Share & $-0.63^{* * *}$ & $(0.23)$ & $-0.63^{* *}$ & $(0.25)$ & $-0.83^{*}$ & $(0.50)$ \\
\hline $\begin{array}{l}\text { Log Distance Lead Arrangers } \\
\text { vs Borrower }\end{array}$ & 1.11 & $(0.70)$ & 1.06 & $(0.71)$ & 0.68 & $(0.69)$ \\
\hline Contract Intensity Index & $8.85^{* * *}$ & $(0.96)$ & $8.28^{* * *}$ & $(0.97)$ & $6.61^{* * *}$ & $(0.93)$ \\
\hline Performance Pricing & $-39.03^{* * *}$ & $(2.42)$ & $-37.43^{* * *}$ & $(2.44)$ & $-35.07^{* * *}$ & $(2.38)$ \\
\hline Relationship Score & $-62.23^{* * *}$ & (23.36) & $-68.48^{* * *}$ & $(23.65)$ & $-96.74^{* * *}$ & $(24.71)$ \\
\hline \multirow{2}{*}{$\begin{array}{l}\text { Syndication } \\
\text { Other Control Variables } \mathcal{E} \\
\text { Fixed Effects }\end{array}$} & $31.12^{* * *}$ & $(4.44)$ & $33.74^{* * *}$ & $(4.48)$ & $32.89^{* * *}$ & $(4.46)$ \\
\hline & \multicolumn{2}{|c|}{ Yes } & \multicolumn{2}{|c|}{ Yes } & \multicolumn{2}{|c|}{ Yes } \\
\hline Observations & \multicolumn{2}{|c|}{12,419} & \multicolumn{2}{|c|}{12,847} & \multicolumn{2}{|c|}{12,847} \\
\hline Adjusted R-squared & \multicolumn{2}{|c|}{0.33} & \multicolumn{2}{|c|}{0.34} & \multicolumn{2}{|c|}{0.39} \\
\hline
\end{tabular}




\section{Table 17}

Drivers of Differences in Loan Pricing - Robustness Test (2/2)

This table presents OLS regressions testing the drivers of pricing differences between non-bank-arranged loans and bankled by using the total cost of borrowing, which includes, additionally to the spread, all fees paid by the borrower, as dependent variable. Columns (2) and (3) present the model without interactions, columns (3) and (4) with interactions. Definitions of all variables can be found in Table 1. Other control variables contain the variables Total HHI, Tightening Standards, Number Main Offices and Local HHI. Fixed effects contain time, industry, loan purpose and loan type fixed effects. Standard errors are clustered by borrower. ${ }^{* *},{ }^{* *}$, and ${ }^{*}$ correspond to the statistical significance levels of $1 \%, 5 \%$ and $10 \%$, respectively.

\begin{tabular}{|c|c|c|c|c|}
\hline \multirow[b]{2}{*}{ Variables } & \multicolumn{2}{|c|}{ Total Cost of Borrowing } & \multicolumn{2}{|c|}{ Total Cost of Borrowing } \\
\hline & Coef. & Se. & Coef. & Se. \\
\hline \multicolumn{5}{|l|}{ Specific Intercepts } \\
\hline Non-Bank-Led & $94.44^{* * *}$ & $(11.79)$ & $332.02^{* * *}$ & $(79.59)$ \\
\hline \multicolumn{5}{|l|}{ Interactions with Non-Bank-Led Dummy } \\
\hline Interacted Cross-Selling Opportunity & - & - & 8.63 & $(12.90)$ \\
\hline Interacted Unrated & - & - & 18.93 & $(15.74)$ \\
\hline Interacted Total Assets & - & - & 3.97 & $(6.18)$ \\
\hline Interacted Market-to-Book & - & - & $12.43^{*}$ & $(7.05)$ \\
\hline Interacted Z-Score & - & - & -5.03 & $(4.99)$ \\
\hline Interacted Leverage & - & - & $-52.27^{*}$ & $(27.39)$ \\
\hline Interacted Relationship Score & - & - & $-303.53^{* * *}$ & $(103.22)$ \\
\hline Interacted Lead Arranger Market Share & - & - & $-23.92^{* * *}$ & $(7.12)$ \\
\hline Interacted Performance Pricing & - & - & $-31.43^{* * *}$ & $(10.38)$ \\
\hline Interacted Total HHI & - & - & $-0.47^{* * *}$ & $(0.11)$ \\
\hline Interacted Tightening Standards & - & - & $-0.58^{* *}$ & $(0.29)$ \\
\hline \multicolumn{5}{|l|}{ Borrower Variables } \\
\hline Z-Score & $-9.19^{* * *}$ & $(1.36)$ & $-8.34^{* * *}$ & $(1.34)$ \\
\hline Leverage & 2.45 & $(5.96)$ & 6.80 & $(5.85)$ \\
\hline Unrated & -3.3 & $(3.64)$ & -4.75 & $(3.73)$ \\
\hline Log Total Assets & 1.88 & $(1.32)$ & 1.55 & $(1.34)$ \\
\hline Log Age & $-2.35^{*}$ & $(1.25)$ & $-2.21^{*}$ & $(1.25)$ \\
\hline EBIT/Total Assets & $-52.76^{* * *}$ & $(16.14)$ & $-55.21^{* * *}$ & $(15.24)$ \\
\hline Market-to-Book & $2.77^{*}$ & $(1.60)$ & 0.69 & $(1.57)$ \\
\hline Public Debt Issuance & 5.04 & $(4.14)$ & 4.72 & $(4.14)$ \\
\hline Past Non-Bank Loans & $31.60^{* * *}$ & $(10.40)$ & $30.37^{* * *}$ & $(10.24)$ \\
\hline Log Number Prior Loans & 1.46 & $(1.76)$ & 1.27 & $(1.75)$ \\
\hline Cross-Selling Opportunity & $3.83^{*}$ & $(2.31)$ & 3.51 & $(2.30)$ \\
\hline \multicolumn{5}{|l|}{ Loan Variables } \\
\hline Log Facility Amount & -1.39 & $(1.20)$ & -0.92 & $(1.21)$ \\
\hline Log Syndicate Size & $-18.76^{* * *}$ & $(2.46)$ & $-18.99^{* * *}$ & $(2.45)$ \\
\hline Log Maturity & $-76.33^{* * *}$ & $(10.36)$ & $-76.84^{* * *}$ & $(10.37)$ \\
\hline Secured & $12.57^{* * *}$ & $(4.85)$ & $12.53^{* * *}$ & $(4.81)$ \\
\hline Sponsored & $12.35^{* * *}$ & $(3.61)$ & $11.24^{* * *}$ & $(3.64)$ \\
\hline End of Quarter Loan & -3.03 & $(2.49)$ & -2.71 & $(2.47)$ \\
\hline
\end{tabular}


Table 17 - continued

\begin{tabular}{lcccc}
\hline Refinancing & $-15.47^{* * *}$ & $(3.17)$ & $-15.18^{* * *}$ & $(3.15)$ \\
Lead Arranger Former Lead & $-9.23^{* * *}$ & $(2.69)$ & $-8.51^{* * *}$ & $(2.68)$ \\
Lead Arranger Market Share & $-0.69^{* * *}$ & $(0.26)$ & $-0.75^{* * *}$ & $(0.26)$ \\
Log Distance Lead Arrangers vs Borrower & $2.25^{* * *}$ & $(0.83)$ & $2.39^{* * *}$ & $(0.81)$ \\
Contract Intensity Index & $9.50^{* * *}$ & $(1.19)$ & $9.48^{* * *}$ & $(1.19)$ \\
Performance Pricing & $-34.00^{* * *}$ & $(2.44)$ & $-31.95^{* * *}$ & $(2.44)$ \\
Relationship Score & $-57.13^{* * *}$ & $(22.13)$ & $-47.46^{* *}$ & $(22.17)$ \\
Syndication & $31.19^{* * *}$ & $(4.95)$ & $31.19^{* * *}$ & $(4.87)$ \\
Other Control Variables \& Fixed Effects & \multicolumn{3}{c}{ Yes } \\
Observations & \multicolumn{2}{c}{12,847} \\
Adjusted R-squared & \multicolumn{2}{c}{0.44} \\
\hline
\end{tabular}




\section{Table 18}

Propensity Score Matching

Panel A presents difference in means tests of the all-in drawn spread among lead arranger types based on a propensity score matching with different algorithms using the model of Table 4 . The difference in means are calculated using Student's t-tests. Panel B uses the identified closest neighbors for a multivariate check of the spread markup similar to Table 7. Panel $\mathrm{C}$ conducts similar tests based on Table 8. Definitions of all variables can be found in Table 1. Other control variables contain the variables Total HHI, Tightening Standards, Number Main Offices and Local HHI. Fixed effects contain time, industry, loan purpose and loan type fixed effects. Standard errors are clustered by borrower. ${ }^{* * *},{ }^{* *}$, and ${ }^{*}$ correspond to the statistical significance levels of $1 \%, 5 \%$ and $10 \%$, respectively.

Panel A: Difference in Means

\begin{tabular}{lcc}
\hline & \multicolumn{2}{c}{ Difference in AISD } \\
& $\begin{array}{c}\text { Lead Arrangers } \\
\text { Non-Bank Lead Arrangers vs. Bank }\end{array}$ \\
Estimator & Coef. & Se. \\
\hline Nearest Neighbor $(\mathrm{n}=10)$ & $93.46^{* * *}$ & $(7.41)$ \\
Nearest Neighbor $(\mathrm{n}=50)$ & $93.77^{* * *}$ & $(7.33)$ \\
Gaussian & $93.65^{* * *}$ & $(7.25)$ \\
Epanechnikov & $91.91^{* * *}$ & $(7.38)$ \\
\hline Unmatched Difference from Table 2 & $102.07^{* * *}$ & $(4.43)$ \\
\hline
\end{tabular}

Panel B: Loan Markup

\begin{tabular}{|c|c|c|c|c|c|c|}
\hline \multirow[b]{2}{*}{ Variables } & \multicolumn{2}{|c|}{$\begin{array}{c}\text { Unmatched } \\
\text { Observations } \\
\text { AISD }\end{array}$} & \multicolumn{2}{|c|}{$\begin{array}{l}\text { Nearest Neighbors } \\
(\mathbf{n}=10) \\
\text { AISD }\end{array}$} & \multicolumn{2}{|c|}{$\begin{array}{l}\text { Nearest Neighbors } \\
(\mathrm{n}=50) \\
\text { AISD }\end{array}$} \\
\hline & Coef. & Se. & Coef. & Se. & Coef. & Se. \\
\hline \multicolumn{7}{|l|}{ Specific Intercept } \\
\hline Non-Bank-Led & $105.32^{* * *}$ & (12.18) & $105.08^{* * *}$ & (11.87) & $103.55^{* * *}$ & (12.12) \\
\hline \multicolumn{7}{|l|}{ Borrower Variables } \\
\hline Z-Score & $-7.84^{* * *}$ & $(1.27)$ & $-8.39^{* * *}$ & $(1.67)$ & $-7.68^{* * *}$ & $(1.34)$ \\
\hline Leverage & 9.00 & $(6.19)$ & -1.69 & $(9.22)$ & 7.38 & $(6.83)$ \\
\hline Unrated & -2.85 & $(3.73)$ & 5.34 & $(6.11)$ & -3.51 & $(4.36)$ \\
\hline Log Total Assets & 1.84 & $(1.33)$ & 0.68 & $(1.95)$ & 0.79 & $(1.51)$ \\
\hline Log Age & $-2.57^{* *}$ & $(1.30)$ & $-5.22^{* * *}$ & $(1.83)$ & $-3.43^{* *}$ & $(1.40)$ \\
\hline EBIT/Total Assets & $-55.41^{* * *}$ & (19.14) & $-40.51^{*}$ & $(21.30)$ & $-69.10^{* * *}$ & $(18.26)$ \\
\hline Market-to-Book & 0.45 & $(1.49)$ & $4.92^{* *}$ & $(2.34)$ & 1.14 & $(1.68)$ \\
\hline Public Debt Issuance & 0.42 & $(3.53)$ & 3.08 & $(7.28)$ & 2.77 & $(4.48)$ \\
\hline Past Non-Bank Loans & $22.38^{* *}$ & $(9.59)$ & $15.36^{*}$ & $(9.27)$ & $20.94^{* *}$ & $(9.59)$ \\
\hline Log Number Prior Loans & 1.51 & $(1.71)$ & $7.11^{* * *}$ & $(2.74)$ & $3.38^{*}$ & $(1.91)$ \\
\hline Cross-Selling Opportunity & -1.45 & $(2.29)$ & -3.23 & $(3.67)$ & 0.07 & $(2.57)$ \\
\hline \multicolumn{7}{|l|}{ Loan Variables } \\
\hline Log Facility Amount & $-6.79^{* * *}$ & $(1.16)$ & $-5.40^{* * *}$ & $(1.80)$ & $-7.40^{* * *}$ & $(1.33)$ \\
\hline Log Syndicate Size & $-18.44^{* * *}$ & $(2.35)$ & $-21.48^{* * *}$ & $(4.18)$ & $-17.71^{* * *}$ & $(2.85)$ \\
\hline Log Maturity & $-12.18^{* * *}$ & $(2.76)$ & $-9.70^{* *}$ & $(4.02)$ & $-11.98^{* * *}$ & $(3.05)$ \\
\hline Secured & $15.27^{* * *}$ & $(3.78)$ & $18.69^{* * *}$ & $(6.32)$ & $9.25^{* *}$ & $(4.56)$ \\
\hline Sponsored & $11.94^{* * *}$ & $(3.57)$ & $15.61^{* * *}$ & $(5.18)$ & $14.69^{* * *}$ & $(4.03)$ \\
\hline
\end{tabular}


Table 18 Panel B - continued

\begin{tabular}{|c|c|c|c|c|c|c|}
\hline End of Quarter Loan & -0.77 & $(2.51)$ & 1.74 & $(3.95)$ & 1.06 & $(2.86)$ \\
\hline Refinancing & $-10.86^{* * *}$ & $(2.87)$ & $-14.25^{* * *}$ & $(4.62)$ & $-11.70^{* * *}$ & $(3.25)$ \\
\hline Lead Arranger Former Lead & $-6.86^{* * *}$ & $(2.62)$ & $-8.45^{*}$ & $(4.60)$ & $-8.75^{* * *}$ & $(3.05)$ \\
\hline Lead Arranger Market Share & $-0.56^{* *}$ & $(0.23)$ & -0.28 & $(0.34)$ & $-0.61^{* *}$ & $(0.25)$ \\
\hline Log Distance Lead Arrangers vs Borrower & 0.99 & $(0.73)$ & 1.19 & $(1.05)$ & $1.55^{* *}$ & $(0.78)$ \\
\hline Contract Intensity Index & $8.35^{* * *}$ & $(0.97)$ & $7.96^{* * *}$ & $(1.56)$ & $8.55^{* * *}$ & $(1.11)$ \\
\hline Performance Pricing & $-40.19^{* * *}$ & $(2.46)$ & $-42.23^{* * *}$ & $(3.92)$ & $-38.99^{* * *}$ & $(2.80)$ \\
\hline Relationship Score & $-76.90^{* * *}$ & $(23.21)$ & $-118.73^{* * *}$ & $(40.69)$ & $-98.93^{* * *}$ & $(26.91)$ \\
\hline Syndication & $33.52^{* * *}$ & $(4.55)$ & $42.68^{* * *}$ & $(7.31)$ & $34.42^{* * *}$ & $(5.05)$ \\
\hline Other Control Variables E Fixed Effects & \multicolumn{2}{|c|}{ Yes } & \multicolumn{2}{|c|}{ Yes } & \multicolumn{2}{|c|}{ Yes } \\
\hline Observations & \multicolumn{2}{|c|}{12,847} & \multicolumn{2}{|c|}{4,772} & \multicolumn{2}{|c|}{9,487} \\
\hline Adjusted R-squared & \multicolumn{2}{|c|}{0.33} & \multicolumn{2}{|c|}{0.33} & \multicolumn{2}{|c|}{0.32} \\
\hline
\end{tabular}

Panel C: Drivers of Loan Markup

\begin{tabular}{|c|c|c|c|c|c|c|}
\hline \multirow[b]{3}{*}{ Variables } & \multirow{2}{*}{\multicolumn{2}{|c|}{$\begin{array}{c}\text { Unmatched } \\
\text { Observations } \\
\text { AISD }\end{array}$}} & \multirow{2}{*}{\multicolumn{2}{|c|}{$\begin{array}{l}\text { Nearest Neighbors } \\
(\mathbf{n}=10) \\
\text { AISD }\end{array}$}} & \multirow{2}{*}{\multicolumn{2}{|c|}{$\begin{array}{c}\text { Nearest Neighbors } \\
(\mathrm{n}=50) \\
\text { AISD }\end{array}$}} \\
\hline & & & & & & \\
\hline & Coef. & Se. & Coef. & Se. & Coef. & Se. \\
\hline \multicolumn{7}{|l|}{ Specific Intercept } \\
\hline Non-Bank-Led & $273.79^{* * *}$ & $(78.77)$ & $262.59^{* * *}$ & $(80.36)$ & $247.31^{* * *}$ & $(79.17)$ \\
\hline \multicolumn{7}{|l|}{ Interactions with Non-Bank-Led Dummy } \\
\hline Interacted Cross-Selling Opportunity & 8.24 & $(12.99)$ & 12.6 & $(13.00)$ & 7.91 & $(13.07)$ \\
\hline Interacted Unrated & $35.15^{* *}$ & $(14.82)$ & $30.94^{* *}$ & $(15.69)$ & $38.06^{* *}$ & $(15.06)$ \\
\hline Interacted Total Assets & 10.03 & $(6.14)$ & $11.03^{*}$ & $(6.41)$ & $11.63^{*}$ & $(6.28)$ \\
\hline Interacted Market-to-Book & $18.57^{* *}$ & $(7.58)$ & $16.22^{* *}$ & $(7.66)$ & $17.60^{* *}$ & $(7.61)$ \\
\hline Interacted Z-Score & -5.29 & $(5.33)$ & -6.24 & $(5.34)$ & -5.07 & $(5.37)$ \\
\hline Interacted Leverage & $-53.46^{*}$ & $(27.40)$ & $\begin{array}{c}-51.97^{*} \\
-\end{array}$ & $(28.06)$ & $-52.12^{*}$ & $(27.64)$ \\
\hline Interacted Relationship Score & $-309.32^{* * *}$ & $(107.94)$ & $339.41^{* * *}$ & $(109.91)$ & $-302.39^{* * *}$ & $(108.71)$ \\
\hline Interacted Lead Arranger Market Share & $-27.85^{* * *}$ & $(7.42)$ & $-28.76^{* * *}$ & $(7.58)$ & $-27.78^{* * *}$ & $(7.54)$ \\
\hline Interacted Performance Pricing & $-36.45^{* * *}$ & $(10.84)$ & $-35.22^{* * *}$ & $(11.24)$ & $-37.10^{* * *}$ & $(10.95)$ \\
\hline Interacted Total HHI & $-0.42^{* * *}$ & $(0.11)$ & $-0.40^{* * *}$ & $(0.12)$ & $-0.40^{* * *}$ & $(0.12)$ \\
\hline Interacted Tightening Standards & $-0.72^{* *}$ & $(0.31)$ & -0.44 & $(0.31)$ & $-0.57^{*}$ & $(0.31)$ \\
\hline \multicolumn{7}{|l|}{ Borrower Variables } \\
\hline Z-Score & $-6.97^{* * *}$ & $(1.20)$ & $-6.60^{* * *}$ & $(1.54)$ & $-6.78^{* * *}$ & $(1.29)$ \\
\hline Leverage & $13.65^{* *}$ & $(6.04)$ & 7.62 & $(9.07)$ & $12.63^{*}$ & $(6.70)$ \\
\hline Unrated & -5.34 & $(3.81)$ & -1.07 & $(6.62)$ & -7.27 & $(4.52)$ \\
\hline Log Total Assets & 1.15 & $(1.33)$ & -1.63 & $(2.05)$ & -0.35 & $(1.54)$ \\
\hline Log Age & $-2.43^{*}$ & $(1.28)$ & $-4.85^{* * *}$ & $(1.77)$ & $-3.24^{* *}$ & $(1.38)$ \\
\hline EBIT/Total Assets & $-57.87^{* * *}$ & $(17.84)$ & $-45.07^{* *}$ & $(21.48)$ & $-70.00^{* * *}$ & $(18.17)$ \\
\hline Market-to-Book & -2.24 & $(1.37)$ & -0.23 & $(1.95)$ & -2.04 & $(1.50)$ \\
\hline Public Debt Issuance & -0.05 & $(3.52)$ & 2.6 & $(7.24)$ & 2.43 & $(4.46)$ \\
\hline Past Non-Bank Loans & $21.04^{* *}$ & $(9.54)$ & $15.64^{*}$ & $(9.31)$ & $19.99^{* *}$ & $(9.56)$ \\
\hline
\end{tabular}


Table 18 Panel C - continued

\begin{tabular}{|c|c|c|c|c|c|c|}
\hline Log Number Prior Loans & 1.27 & $(1.69)$ & $6.42^{* *}$ & $(2.68)$ & 3.07 & $(1.88)$ \\
\hline Cross-Selling Opportunity & -1.67 & $(2.27)$ & -4.48 & $(3.52)$ & -0.19 & $(2.53)$ \\
\hline \multicolumn{7}{|l|}{ Loan Variables } \\
\hline Log Facility Amount & $-6.19^{* * *}$ & $(1.16)$ & $-4.47^{* *}$ & $(1.80)$ & $-6.67^{* * *}$ & $(1.34)$ \\
\hline Log Syndicate Size & $-18.65^{* * *}$ & $(2.33)$ & $-21.40^{* * *}$ & $(4.12)$ & $-17.84^{* * *}$ & $(2.83)$ \\
\hline Log Maturity & $-12.68^{* * *}$ & $(2.74)$ & $-10.87^{* * *}$ & $(3.93)$ & $-12.64^{* * *}$ & $(3.03)$ \\
\hline Secured & $15.17^{* * *}$ & $(3.71)$ & $19.43^{* * *}$ & $(6.02)$ & $9.19^{* *}$ & $(4.45)$ \\
\hline Sponsored & $10.50^{* * *}$ & $(3.60)$ & $12.76^{* *}$ & $(5.37)$ & $12.76^{* * *}$ & $(4.09)$ \\
\hline End of Quarter Loan & -0.53 & $(2.50)$ & 2.51 & $(3.89)$ & 1.35 & $(2.85)$ \\
\hline Refinancing & $-10.44^{* * *}$ & $(2.85)$ & $-14.12^{* * *}$ & $(4.54)$ & $-11.33^{* * *}$ & $(3.22)$ \\
\hline Lead Arranger Former Lead & $-6.11^{* *}$ & $(2.60)$ & -7.06 & $(4.56)$ & $-7.90^{* * *}$ & $(3.03)$ \\
\hline Lead Arranger Market Share & $-0.62^{* * *}$ & $(0.23)$ & -0.36 & $(0.34)$ & $-0.68^{* * *}$ & $(0.25)$ \\
\hline Log Distance Lead Arrangers vs & 1.13 & $(0.70)$ & 1.41 & $(0.98)$ & $1.67^{* *}$ & $(0.75)$ \\
\hline \multicolumn{7}{|l|}{ Borrower } \\
\hline Contract Intensity Index & $8.35^{* * *}$ & $(0.96)$ & $7.96^{* * *}$ & $(1.55)$ & $8.55^{* * *}$ & $(1.10)$ \\
\hline Performance Pricing & $-37.74^{* * *}$ & $(2.43)$ & $-36.60^{* * *}$ & $(3.80)$ & $-35.83^{* * *}$ & $(2.76)$ \\
\hline Relationship Score & $-66.69^{* * *}$ & $(23.29)$ & $-80.14^{*}$ & $(41.73)$ & $-84.57^{* * *}$ & $(27.08)$ \\
\hline Syndication & $33.30^{* * *}$ & $(4.43)$ & $42.82^{* * *}$ & $(7.05)$ & $34.24^{* * *}$ & $(4.89)$ \\
\hline Other Control Variables $\mathcal{E}$ Fixed Effects & \multicolumn{2}{|c|}{ Yes } & \multicolumn{2}{|c|}{ Yes } & \multicolumn{2}{|c|}{ Yes } \\
\hline Observations & \multicolumn{2}{|c|}{12,847} & \multicolumn{2}{|c|}{4,772} & \multicolumn{2}{|c|}{9,487} \\
\hline Adjusted R-squared & \multicolumn{2}{|c|}{0.34} & \multicolumn{2}{|c|}{0.35} & \multicolumn{2}{|c|}{0.33} \\
\hline
\end{tabular}




\section{Table 19}

Quality of Due Diligence/Monitoring - Robustness Test

Panel A presents the coefficient estimates of OLS regressions with the z-score at different points in time as dependent variables. Panel B presents the coefficient estimates of probit regressions with the actual default rate at different points in time as dependent variables. Definitions of all variables can be found in Table 1. Other control variables contain the variables Total HHI, Tightening Standards, Number Main Offices and Local HHI. Fixed effects contain time, industry, loan purpose and loan type fixed effects. In Panel B, I lose some observations due to perfect failure prediction as some years do not have actual defaults. Standard errors are clustered by borrower. ${ }^{* *},{ }^{* *}$, and ${ }^{*}$ correspond to the statistical significance levels of $1 \%, 5 \%$ and $10 \%$, respectively.

Panel A: Z-score

\begin{tabular}{|c|c|c|c|c|c|c|c|c|}
\hline \multirow[b]{2}{*}{ Variables } & \multicolumn{2}{|c|}{ Z-Score at Year 0} & \multicolumn{2}{|c|}{ Z-Score at Year 1} & \multicolumn{2}{|c|}{ Z-Score at Year 2} & \multicolumn{2}{|c|}{ Z-Score at Year 3} \\
\hline & Coef. & Se. & Coef. & Se. & Coef. & Se. & Coef. & Se. \\
\hline \multicolumn{9}{|l|}{ Specific Intercept } \\
\hline Non-Bank-Led & -0.07 & $(0.09)$ & -0.10 & $(0.11)$ & $-0.39^{* * *}$ & $(0.14)$ & -0.13 & $(0.13)$ \\
\hline \multicolumn{9}{|l|}{ Borrower Variables } \\
\hline Z-Score & $0.54^{* * *}$ & $(0.03)$ & $0.53^{* * *}$ & $(0.03)$ & $0.48^{* * *}$ & $(0.04)$ & $0.46^{* * *}$ & $(0.04)$ \\
\hline Leverage & -0.12 & $(0.10)$ & 0.04 & $(0.12)$ & -0.03 & $(0.13)$ & 0.21 & $(0.13)$ \\
\hline Unrated & $0.17^{* * *}$ & $(0.04)$ & $0.18^{* * *}$ & $(0.06)$ & $0.12^{*}$ & $(0.06)$ & $0.22^{* * *}$ & $(0.07)$ \\
\hline Log Total Assets & $-0.07^{* * *}$ & $(0.02)$ & $-0.08^{* * *}$ & $(0.02)$ & $-0.08^{* * *}$ & $(0.03)$ & -0.05 & $(0.03)$ \\
\hline Log Age & 0.01 & $(0.02)$ & 0.02 & $(0.02)$ & $0.05^{*}$ & $(0.03)$ & $0.07^{* *}$ & $(0.04)$ \\
\hline EBIT/Total Assets & $0.75^{* *}$ & $(0.32)$ & $0.70^{*}$ & $(0.37)$ & $1.07^{* *}$ & $(0.44)$ & $0.70^{* *}$ & $(0.33)$ \\
\hline Market-to-Book & $-0.21^{* * *}$ & $(0.03)$ & $-0.24^{* * *}$ & $(0.04)$ & $-0.23^{* * *}$ & $(0.04)$ & $-0.20^{* * *}$ & $(0.05)$ \\
\hline Public Debt Issuance & $-0.18^{* * *}$ & $(0.04)$ & $-0.17^{* * *}$ & $(0.06)$ & $-0.21^{* * *}$ & $(0.07)$ & $-0.18^{* *}$ & $(0.07)$ \\
\hline Past Non-Bank Loans & 0.02 & $(0.07)$ & 0.02 & $(0.10)$ & 0.38 & $(0.30)$ & 0.27 & $(0.19)$ \\
\hline Log Number Prior Loans & -0.03 & $(0.02)$ & -0.01 & $(0.03)$ & 0.00 & $(0.03)$ & 0.00 & $(0.04)$ \\
\hline Cross-Selling Opportunity & $0.09^{* * *}$ & $(0.03)$ & 0.00 & $(0.04)$ & $-0.13^{* * *}$ & $(0.05)$ & $-0.15^{* *}$ & $(0.06)$ \\
\hline \multicolumn{9}{|l|}{ Loan Variables } \\
\hline AISD & $-0.00^{* * *}$ & $(0.00)$ & $-0.00^{* * *}$ & $(0.00)$ & $-0.00^{* * *}$ & $(0.00)$ & $-0.00^{* * *}$ & $(0.00)$ \\
\hline Log Facility Amount & -0.02 & $(0.02)$ & $-0.06^{* * *}$ & $(0.02)$ & $-0.06^{* *}$ & $(0.02)$ & $-0.08^{* * *}$ & $(0.03)$ \\
\hline Log Syndicate Size & 0.01 & $(0.03)$ & -0.02 & $(0.03)$ & 0.02 & $(0.04)$ & -0.04 & $(0.04)$ \\
\hline Log Maturity & -0.04 & $(0.04)$ & -0.06 & $(0.05)$ & -0.07 & $(0.05)$ & -0.08 & $(0.06)$ \\
\hline Secured & -0.08 & $(0.05)$ & -0.09 & $(0.06)$ & $-0.15^{* *}$ & $(0.07)$ & -0.12 & $(0.08)$ \\
\hline
\end{tabular}


Table 19 Panel A - continued

\begin{tabular}{|c|c|c|c|c|c|c|c|c|}
\hline Sponsored & $-0.10^{* *}$ & $(0.05)$ & $-0.16^{* * *}$ & $(0.06)$ & $-0.25^{* * *}$ & $(0.07)$ & $-0.25^{* * *}$ & $(0.08)$ \\
\hline End of Quarter Loan & $0.08^{* *}$ & $(0.04)$ & 0.03 & $(0.04)$ & 0.06 & $(0.05)$ & 0.03 & $(0.06)$ \\
\hline Refinancing & -0.04 & $(0.05)$ & 0.05 & $(0.05)$ & -0.01 & $(0.06)$ & 0.02 & $(0.07)$ \\
\hline Lead Arranger Former Lead & $0.07^{* *}$ & $(0.03)$ & -0.01 & $(0.04)$ & 0.00 & $(0.05)$ & 0.01 & $(0.05)$ \\
\hline Lead Arranger Market Share & $-0.01^{*}$ & $(0.00)$ & 0.00 & $(0.01)$ & 0.00 & $(0.01)$ & 0.00 & $(0.01)$ \\
\hline Log Distance Lead Arrangers vs & -0.02 & $(0.01)$ & & & & & & \\
\hline Borrower & & & -0.01 & $(0.01)$ & -0.01 & $(0.02)$ & 0.00 & $(0.02)$ \\
\hline Contract Intensity Index & $-0.02^{*}$ & $(0.01)$ & -0.02 & $(0.01)$ & 0.00 & $(0.02)$ & -0.02 & $(0.02)$ \\
\hline Performance Pricing & 0.05 & $(0.04)$ & 0.02 & $(0.05)$ & -0.02 & $(0.05)$ & 0.06 & $(0.06)$ \\
\hline Relationship Score & 0.17 & $(0.33)$ & 0.31 & $(0.45)$ & 0.40 & $(0.41)$ & 0.41 & $(0.43)$ \\
\hline Other Control Variables \& Fixed Effects & \multicolumn{2}{|c|}{ Yes } & \multicolumn{2}{|c|}{ Yes } & \multicolumn{2}{|c|}{ Yes } & \multicolumn{2}{|c|}{ Yes } \\
\hline Observations & \multicolumn{2}{|c|}{12,847} & \multicolumn{2}{|c|}{11,283} & \multicolumn{2}{|c|}{9,825} & \multicolumn{2}{|c|}{8,714} \\
\hline Pseudo R-squared & \multicolumn{2}{|c|}{0.41} & \multicolumn{2}{|c|}{0.35} & \multicolumn{2}{|c|}{0.31} & \multicolumn{2}{|c|}{0.27} \\
\hline
\end{tabular}

Panel B: Default rate

\begin{tabular}{|c|c|c|c|c|c|c|}
\hline \multirow[b]{2}{*}{ Variables } & \multicolumn{2}{|c|}{ Default During Loan } & \multicolumn{2}{|c|}{$\begin{array}{c}\text { Default Within One } \\
\text { Year After Loan } \\
\text { Maturity }\end{array}$} & \multicolumn{2}{|c|}{$\begin{array}{c}\text { Default After Loar } \\
\text { Maturity }\end{array}$} \\
\hline & Coef. & Se. & Coef. & Se. & Coef. & Se. \\
\hline \multicolumn{7}{|l|}{ Specific Intercept } \\
\hline Non-Bank-Led & 0.01 & $(0.19)$ & $-1.04^{* * *}$ & $(0.21)$ & $-0.70^{* *}$ & $(0.34)$ \\
\hline \multicolumn{7}{|l|}{ Borrower Variables } \\
\hline Z-Score & -0.01 & $(0.04)$ & -0.02 & $(0.05)$ & -0.02 & $(0.04)$ \\
\hline Leverage & $0.35^{* *}$ & $(0.14)$ & 0.01 & $(0.22)$ & 0.12 & $(0.16)$ \\
\hline Unrated & $-0.63^{* * *}$ & $(0.09)$ & $-0.36^{* *}$ & $(0.14)$ & $-0.36^{* * *}$ & $(0.11)$ \\
\hline Log Total Assets & $0.06^{*}$ & $(0.04)$ & -0.04 & $(0.05)$ & 0.03 & $(0.04)$ \\
\hline Log Age & -0.03 & $(0.04)$ & 0.06 & $(0.05)$ & 0.07 & $(0.06)$ \\
\hline EBIT/Total Assets & $-0.61^{* * *}$ & $(0.23)$ & 0.53 & $(0.52)$ & 0.22 & $(0.39)$ \\
\hline Market-to-Book & -0.07 & $(0.04)$ & -0.11 & $(0.07)$ & $-0.11^{* *}$ & $(0.05)$ \\
\hline Public Debt Issuance & $0.17^{*}$ & $(0.09)$ & $0.29^{* *}$ & $(0.12)$ & $0.21^{* *}$ & $(0.10)$ \\
\hline
\end{tabular}


Table 19 Panel B - continued

\begin{tabular}{|c|c|c|c|c|c|c|}
\hline Past Non-Bank Loans & $-0.49^{* *}$ & $(0.22)$ & -0.57 & $(0.38)$ & -0.36 & $(0.22)$ \\
\hline Log Number Prior Loans & 0.00 & $(0.05)$ & -0.06 & $(0.06)$ & 0.02 & $(0.06)$ \\
\hline Cross-Selling Opportunity & $-0.14^{* *}$ & $(0.06)$ & -0.02 & $(0.08)$ & 0.04 & $(0.06)$ \\
\hline Loan Variables & & & & & & \\
\hline AISD & $0.00^{* * *}$ & $(0.00)$ & 0.00 & $(0.00)$ & $0.00^{* * *}$ & $(0.00)$ \\
\hline Log Facility Amount & $0.08^{* *}$ & $(0.03)$ & $0.12^{* * *}$ & $(0.05)$ & $0.09^{* * *}$ & $(0.04)$ \\
\hline Log Syndicate Size & 0.02 & $(0.05)$ & -0.17 & $(0.11)$ & $-0.14^{* *}$ & $(0.06)$ \\
\hline Log Maturity & $0.26^{* * *}$ & $(0.07)$ & $-0.29^{* * *}$ & $(0.08)$ & $-0.35^{* * *}$ & $(0.06)$ \\
\hline Secured & $0.30^{* * *}$ & $(0.09)$ & 0.11 & $(0.14)$ & 0.09 & $(0.10)$ \\
\hline Sponsored & 0.03 & $(0.10)$ & $0.22^{*}$ & $(0.12)$ & 0.01 & $(0.12)$ \\
\hline End of Quarter Loan & -0.01 & $(0.07)$ & 0.07 & $(0.11)$ & 0.08 & $(0.08)$ \\
\hline Refinancing & $-0.18^{* *}$ & $(0.07)$ & 0.02 & $(0.12)$ & 0.05 & $(0.09)$ \\
\hline Lead Arranger Former Lead & 0.08 & $(0.07)$ & 0.16 & $(0.10)$ & 0.01 & $(0.06)$ \\
\hline Lead Arranger Market Share & 0.00 & $(0.01)$ & 0.00 & $(0.01)$ & -0.01 & $(0.01)$ \\
\hline $\begin{array}{l}\text { Log Distance Lead Arrangers vs } \\
\text { Borrower }\end{array}$ & $-0.04^{* *}$ & $(0.02)$ & 0.01 & $(0.03)$ & 0.03 & $(0.03)$ \\
\hline Contract Intensity Index & $0.04^{*}$ & $(0.02)$ & -0.01 & $(0.03)$ & $0.04^{*}$ & $(0.02)$ \\
\hline Performance Pricing & 0.08 & $(0.06)$ & -0.06 & $(0.10)$ & 0.01 & $(0.08)$ \\
\hline Relationship Score & 0.32 & $(0.57)$ & 1.21 & $(0.85)$ & 0.53 & $(0.62)$ \\
\hline Other Control Variables \& Fixed Effects & \multicolumn{2}{|c|}{ Yes } & \multicolumn{2}{|c|}{ Yes } & \multicolumn{2}{|c|}{ Yes } \\
\hline Observations & \multicolumn{2}{|c|}{12,839} & \multicolumn{2}{|c|}{11,115} & \multicolumn{2}{|c|}{11,516} \\
\hline Pseudo R-squared & \multicolumn{2}{|c|}{0.21} & \multicolumn{2}{|c|}{0.13} & \multicolumn{2}{|c|}{0.14} \\
\hline
\end{tabular}




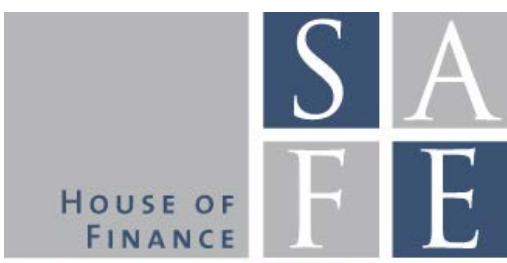

WORKING PAPER SERIES

\section{Recent Issues}

No. 99 Marcel Grupp, Christian Rauch, Marc Umber, Uwe Walz

No.98 Tobias Niedrig, Helmut Gründl

No. 97 Tobias Niedrig

No.96 Jens-Hinrich Binder

No. 95 Loriana Pelizzon, Marti G. Subrahmanyam, Davide Tomio, Jun Uno

No. 94 Claudia Lambert, Felix Noth, Ulrich Schüwer

No. 93 Shafik Hebous, Tom Zimmermann

No.92 Christoph Hambel, Holger Kraft, Eduardo S. Schwartz

No.91 Anne-Caroline Hüser

No. $90 \quad$ Pinar Topal

No. 89 Julia Braun, Alfons J. Weichenrieder

No. 88 Ester Faia, Beatrice Weder di Mauro

No. 87 Iñaki Aldasoro, Domenico Delli Gatti, Ester Faia
The Influence of Leveraged Buyouts on Target Firms' Competitors

The Effects of Contingent Convertible (CoCo) Bonds on Insurers' Capital Requirements Under Solvency II

Optimal Asset Allocation for interconnected Life Insurers in the Low Interest Rate Environment under Solvency Regulation

Banking Union and the Governance of Credit Institutions - A Legal Perspective

Sovereign Credit Risk, Liquidity, and ECB Intervention: Deus Ex Machina?

How Do Banks React to Catastrophic Events? Evidence from Hurricane Katrina

Revisiting the Narrative Approach of Estimating Tax Multipliers

Optimal Carbon Abatement in a Stochastic Equilibrium Model with Climate Change

Too Interconnected to Fail: A Survey of the Interbank Networks Literature

Fiscal Stimulus and Labor Market Flexibility

Does Exchange of Information between Tax Authorities Influence Multinationals' Use of Tax Havens?

Cross-Border Resolution of Global Banks

Bank Networks: Contagion, Systemic Risk and Prudential Policy 